\title{
Reactive Sintering of Aluminum Titanate
}

\author{
Irene Barrios de Arenas \\ Instituto Universitario de Tecnología \\ "Dr Federico Rivero Palacio" \\ Venezuela
}

\section{Introduction}

The high thermal shock resistance due to the negligible thermal expansion coefficient, additional to its low thermal conductivity and good chemical resistance makes the aluminum titanate $\left(\mathrm{Al}_{2} \mathrm{TiO}_{5}\right)$ a suitable material for different technological applications. It is a ceramic material consisting of a mixture of alumina $\left(\mathrm{Al}_{2} \mathrm{O}_{3}\right)$ and titania $\left(\mathrm{TiO}_{2}\right)$ forming solid solution with stoichiometric proportion of the components: $\mathrm{Al}_{2} \mathrm{O}_{3} \cdot \mathrm{TiO}_{2}$ or $\mathrm{Al}_{2} \mathrm{TiO}_{5}$. It is prepared by heating a mixture of alumina and titania at temperature above $1350^{\circ} \mathrm{C}$, in air atmosphere. Pure Aluminum Titanate is unstable at temperatures above $750^{\circ} \mathrm{C}$, when the solid solution decomposes, following a eutectoid reaction, into two separate phases $\mathrm{Al}_{2} \mathrm{O}_{3}$ and $\mathrm{TiO}_{2}$. For this reason Aluminum Titanate ceramics are doped usually with $\mathrm{MgO}, \mathrm{SiO}_{2}$ and $\mathrm{ZrO}_{2}$ in order to stabilize the solid solution structure.

Unfortunately, the expansion crystal structure anisotropy that promotes the low thermal expansion coefficients provokes microcracking, as a result of anisotropy of thermal expansion along the three primary axes of the crystal lattice (a single crystal of Aluminum Titanate expands along two axes and contracts on the third one when heated), therefore a low mechanical strength and, on the other hand, the low thermal stability below $1280^{\circ} \mathrm{C}$ restricts its technical use.

Aluminum Titanate ceramic materials have many technological applications, among others, as thermal insulation liner, soot particulate filter in diesel engines, spacing rings of catalytic converters, in the foundry crucibles, launders, nozzles, riser tubes, pouring spouts and thermocouples for non-ferrous metallurgy and master moulds glass industries.

\section{Fundamentals of low thermal expansion coefficient aluminum titanate $\left(\mathrm{Al}_{2} \mathrm{TiO}_{5}\right)$ ceramics}

There are two important features to achieve a very low thermal expansion coefficient, in crystalline ceramic structures highly anisotropic. The first aspect involves unit cell crystalline chemistry. The coefficients of thermal expansion of the crystal axes are controlled to develop solid solutions, in an attempt to ensure that the sum of the coefficients of the principal axes gives zero. In the case of polycrystalline ceramic materials, the volumetric 
thermal expansion coefficient is related to the sum of unit cells coefficients of thermal expansion. In orthorhombic crystal structures as that of the pseudobrookita, material object of this work, the relationship is:

$$
\beta_{\mathrm{v}}=\alpha_{a}+\alpha_{b}+\alpha_{c}
$$

Where $\beta_{\mathrm{v}}=$ Volumetric thermal expansion coefficient

$\alpha_{i}=$ Thermal expansion coefficients of principal crystal axes

As the anisotropic crystalline structures have principal axes with positive and negative expansion coefficients, it is necessary to examine the thermal expansion coefficients of all the members of an isostructural family and chemically design a solid solution whose $\alpha_{i}$ addition is close to zero. Bayer $(1971 ; 1973)$, studied the unit cell, of the pseudobrookita structure. Provided that the sum of the thermal expansion coefficients of the principal axes $\left(\alpha_{i}\right)$ add zero, it occurs an inevitable combination of positive and negative values. This condition leads to, very high (at GPa levels), micromechanical stresses at grain boundaries, during cooling from the temperatures of ceramic processing. The development of these internal stresses, promotes the breakdown of the grain boundaries, which causes a decrease in the structural integrity of the polycrystalline ceramic body. However, the existence of this microcracking depends on the microstructural grain size. Kuszyk and Bradt (1973) noted that the rigidity of the ceramic body decreased as increasing grain size, determining a critical grain size. Once determined this size, is simply necessary a process production control to achieve a compromise between the microcracking and the required structural mechanical resistance. Another possibility is to produce a material with large grain size and extensive microcracking with low mechanical resistance but where the main interest is the low thermal expansion (Hasselman, 1977; Stingl, 1986; Sheppard 1988; Huber, 1988). However, several researchers (Buessem, 1966; Cleveland, 1977; 1978) have suggested that the presence of the extensive internal microcracking, contributes to an increase in the resistance to fracture of these polycrystalline ceramics highly anisotropic, activating mechanisms such as: shielding, branching or cracks deviation. Experimentally, this hypothesis has not been demonstrated, so it is a concept that must be handled carefully.

\section{Aluminum titanate $\left(\mathrm{Al}_{2} \mathrm{TiO}_{5}\right)$ ceramics}

The $\mathrm{Al}_{2} \mathrm{TiO}_{5}$ is a one mole $\mathrm{Al}_{2} \mathrm{O}_{3}$ and one mole $\mathrm{TiO}_{2}$ compound. This material is conventionally prepared by reactive sintering of $\mathrm{Al}_{2} \mathrm{O}_{3}$ and $\mathrm{TiO}_{2}$ powders. Its interest as polycrystalline ceramic material arose from the work of Bachmann (1948), who found that the thermal expansion of aluminum titanate, in the studied temperature range, could be lower than that of the vitreous silica. This material has interesting features for applications such as thermal insulator and can also withstand strong thermal gradients. This aluminum titanate emerged as a promising ceramics for technological applications; summarizing its most important physical properties, in Table 1.

The material presents two major problems: the thermodynamics instability of the $\mathrm{Al}_{2} \mathrm{TiO}_{5}$ below $1280{ }^{\circ} \mathrm{C}$ and its poor mechanical resistance related to an extensive microcracking which is, in turn, responsible for the low thermal expansion. Decomposition can be controlled or at least delayed, with oxides additions, such as MgO (Ishitsuka and col., 1987; 
Wohlfrom and col., 1990) and $\mathrm{Fe}_{2} \mathrm{O}_{3}$ (Tilloca, G., 1991, Brown et al., 1994), which forms solid solutions between the $\mathrm{Al}_{2} \mathrm{TiO}_{5}$ and the isoestructurals $\mathrm{MgTi}_{2} \mathrm{O}_{5}$ and $\mathrm{Fe}_{2} \mathrm{TiO}_{5}$. The mechanical strength can be increased with good results preparing composite materials such as: $\mathrm{Al}_{2} \mathrm{TiO}_{5}$ Mulita (Morishima and col. 1987), $\mathrm{Al}_{2} \mathrm{TiO}_{5}$ - Mulita - $\mathrm{ZrO}_{2}$ (Wohlfrom et al., 1990).

\begin{tabular}{|c|c|c|}
\hline Property & $\mathrm{Al}_{2} \mathrm{TiO}_{5}$ & Reference \\
\hline Density $\left(\mathrm{g} / \mathrm{cm}^{3}\right)$ & 3.702 & Holcombe (1973) \\
\hline $\begin{array}{l}\text { Thermal Expansion Coefficient } \\
\text { Average }\left(\times 10^{-6}{ }^{\circ} C^{-1}\right) \\
\alpha_{a 20-520}-\alpha_{a 20-1000} \\
\alpha_{b 20-520}-\alpha_{b 20-1000} \\
\alpha_{c 20-520}-\alpha_{c 20-1000}\end{array}$ & $\begin{array}{c}-2.9--3 \\
10.3-11.8 \\
20.1-21.8\end{array}$ & Wohlfromm (1990) \\
\hline $\begin{array}{c}\text { Thermal Expansion Coefficient } \\
\text { Average }\left(\times 10^{-6} \mathrm{C}^{-1}\right) \\
\text { Crystallographic } \\
\alpha_{20-520}-\alpha_{20-1000} \\
\text { Macroscopic } \\
\alpha_{20-1000} \\
\alpha_{20-1000} \\
\text { Anisotropy } \\
\Delta \alpha_{20-520}-\Delta \alpha_{20-1000}\end{array}$ & $\begin{array}{l}9.2-10.2 \\
1.0-1.5 \\
1.5-1.7 \\
23-24.8\end{array}$ & $\begin{array}{c}\text { Stingl (1986) } \\
\text { Milosevski (1995) }\end{array}$ \\
\hline Melting Point $\left({ }^{\circ} \mathrm{C}\right)$ & 1860 & Lang (1952) \\
\hline $\begin{array}{l}\text { Elastic Modulus } \\
\qquad \mathrm{E}(\mathrm{GPa})\end{array}$ & $\begin{array}{l}12-18 \\
10-20 \\
13-15\end{array}$ & $\begin{array}{c}\text { Stingl (1986) } \\
\text { Cleveland (1978) } \\
\text { Milosevski (1997) }\end{array}$ \\
\hline Hardness, Hv (GPa) & 5 & Wohlfromm (1990) \\
\hline Bending Strenght, $\sigma(\mathrm{MPa})$ & $\begin{array}{c}4-20 \\
25-40\end{array}$ & Milosevski (1995) \\
\hline Thermal shock resistance $\left(\mathrm{Wm}^{-1}\right)$ & 500 & Stingl (1986) \\
\hline Thermal Conductivity, k(W/mK) & $1.5-2.5$ & $\begin{array}{c}\text { Stingl (1986) } \\
\text { Milosevski (1997) }\end{array}$ \\
\hline
\end{tabular}

Table 1. Aluminum Titanate Physical Properties.

\subsection{Equilibrium diagram}

Lang et al. (1952) studied the $\mathrm{Al}_{2} \mathrm{O}_{3}-\mathrm{TiO}_{2}$ equilibrium diagram (Fig. 1), finding the existence of two allotropic forms of aluminum titanate: $\alpha-\mathrm{Al}_{2} \mathrm{TiO}_{5}$, a high temperature phase, stable between $1820^{\circ} \mathrm{C}$ and the melting point at $1860 \pm 10^{\circ} \mathrm{C}$ and $\beta-\mathrm{Al}_{2} \mathrm{TiO}_{5}$, a low temperature phase stable from room temperature up to $\approx 750^{\circ} \mathrm{C}$ and from $1300^{\circ} \mathrm{C}$ up to inversion temperature $1820^{\circ} \mathrm{C}$ (at intermediate values, it has instability and decomposes to $\mathrm{Al}_{2} \mathrm{O}_{3}+\mathrm{TiO}_{2}$ ). The 
transformation between both phases is spontaneous and reversible; it was found that it is almost impossible to obtain $\alpha-\mathrm{Al}_{2} \mathrm{TiO}_{5}$ at room temperature, being necessary cooling speeds greater than $800 \mathrm{~K} / \mathrm{h}$.)

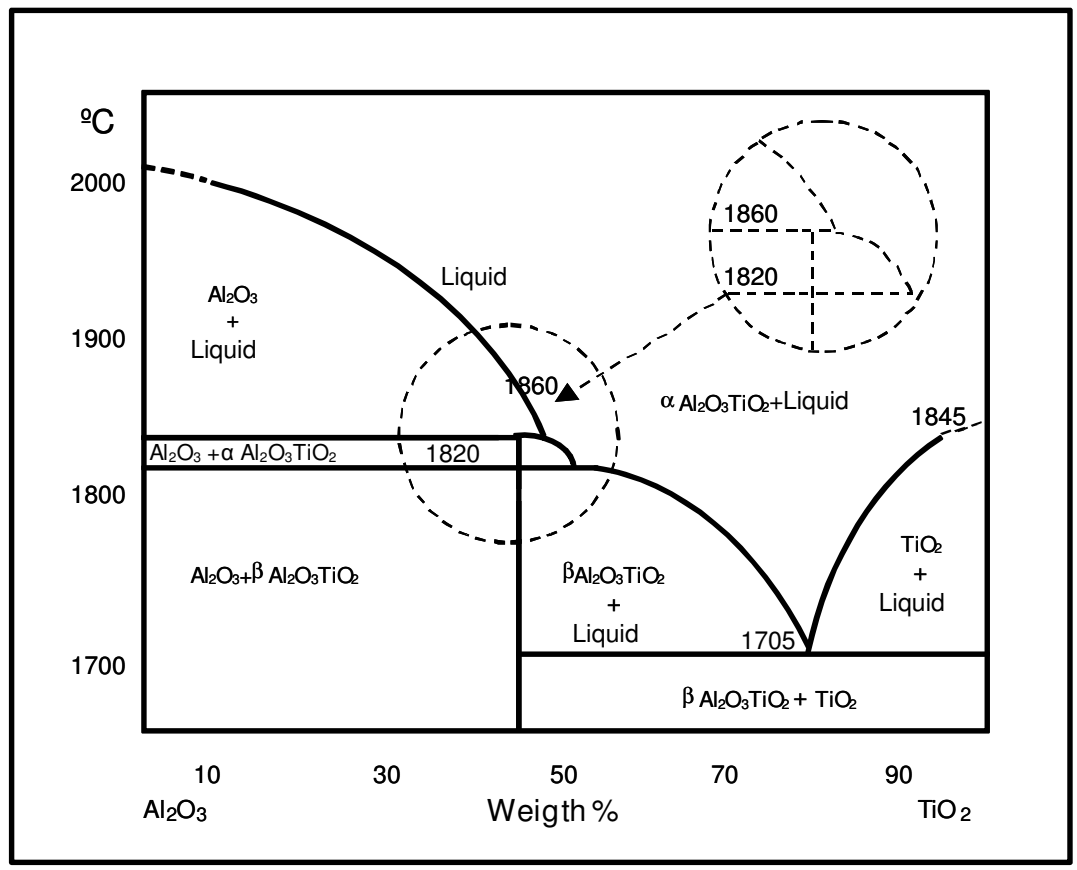

Fig. 1. $\mathrm{Al}_{2} \mathrm{O}_{3}-\mathrm{TiO}_{2}$ Equilibrium Diagram by Lang (1952).

Evidence suggests a congruent transformation of $\alpha-\mathrm{Al}_{2} \mathrm{TiO}_{5}$ at $1860^{\circ} \mathrm{C}$, but the possibility of an incongruent fusion or the existence of a solid solution between $\mathrm{Al}_{2} \mathrm{O}_{3}$ and $\mathrm{Al}_{2} \mathrm{TiO}_{5}$ could not be studied, due to the difficulties of obtaining accurate data, because of the high viscosity of liquid formed.

A second point of importance obtained from this research was the suggestion of an instability region for the $\beta$ - aluminum titanate between $750^{\circ} \mathrm{C}$ and $130^{\circ} \mathrm{C}$. This phenomenon has been confirmed by subsequent research (Fonseca \& Baptista 2003). Lang et al., (1952) concluded that opposing formation and decomposition processes occurred in dynamic equilibrium, promoting decomposition at a certain temperature range, i.e. the $\beta-\mathrm{Al}_{2} \mathrm{TiO}_{5}$ phase is stable above $1300^{\circ} \mathrm{C}$, below this temperature aluminum titanate undergoes an eutectoid transformation according to the reaction:

$$
\mathrm{Al}_{2} \mathrm{TiO}_{5} \Leftrightarrow \mathrm{Al}_{2} \mathrm{O}_{3}+\mathrm{TiO}_{2}
$$




\subsubsection{Effect of oxygen partial pressure in aluminum titanate stability}

The composition and mechanical properties of aluminum titanate are strongly influenced by the partial pressure of oxygen from the surrounding atmosphere. It is well known that the valence of the Ti cation in titanium oxides depends on the partial pressure of oxygen (Jürgen et al. 1996). At high oxygen pressures, $\mathrm{Ti}$ is tetravalent producing $\mathrm{TiO}_{2}$. Due to entropic reasons, at low oxygen pressures (such as for example in air) there is a small fraction of $\mathrm{Ti}^{+3}$, its amount depending on the temperature. By decreasing the partial pressure of oxygen furthermore, the $\mathrm{Ti}^{+3} / \mathrm{Ti}^{+4}$ relationship increases continuously producing $\mathrm{Ti}_{n} \mathrm{O}_{2 n-1}$ Magneli phases and other sub-oxides such as $\mathrm{Ti}_{4} \mathrm{O}_{7}, \mathrm{Ti}_{3} \mathrm{O}_{5}$ and $\mathrm{Ti}_{2} \mathrm{O}_{3}$. The aluminum titanate phase shows similar behavior (Jürgen et al. 1996). Under high $\mathrm{O}_{2}$ pressure the aluminum titanate is almost a stoichiometric composition phase $\mathrm{Al}_{2} \mathrm{TiO}_{5}$. Decreasing the oxygen partial pressure, due to the increase in the $\mathrm{Ti}^{+3} / \mathrm{Ti}^{+4}$ ratios, it occurs a gradual interchange of $\mathrm{Al}^{+3}$ by $\mathrm{Ti}^{+3}$ in the aluminum titanate structure. This exchange results in the stoichiometric $\mathrm{Al}_{2} \mathrm{TiO}_{5}$ decomposition, to the reduced form of aluminum titanate, $\mathrm{Al}_{2} \mathrm{O}_{3}$ and oxygen according to the reaction:

$$
(3-2 \mathrm{z})\left[\left(\mathrm{Al}^{+3}\right)_{2}\left(\mathrm{Ti}^{+4}\right)_{1}\left(\mathrm{O}^{-2}\right)_{5}\right]=\left(\mathrm{Al}_{\mathrm{z}}+3 \mathrm{Ti}_{1-\mathrm{z}}\right)_{2}\left(\mathrm{Ti}^{+4}\right)\left(\mathrm{O}^{-2}\right)_{5}+3(1-\mathrm{z}) \mathrm{Al}_{2} \mathrm{O}_{3}+1 / 2(1-\mathrm{z}) \mathrm{O}_{2}
$$

Decreasing the oxygen potential $(\mathrm{z} \rightarrow 0)$, the decomposition reaction eventually produces $\mathrm{Ti}_{3} \mathrm{O}_{5}$ titanium oxide. The degree of decomposition from $\mathrm{Al}_{2} \mathrm{TiO}_{5}$ to $\mathrm{Ti}_{3} \mathrm{O}_{5}$ can be related to a continuous change of the aluminum titanate parameter network c, (Asbrink et al., 1967).

Considering the solubility between the $\mathrm{Al}_{2} \mathrm{TiO}_{5}$ and the $\mathrm{Ti}_{3} \mathrm{O}_{5}$ under various oxygen pressures, the $\mathrm{Al}_{2} \mathrm{TiO}_{5}$ was described with a subnet model $\left(\mathrm{Al}^{+3}, \mathrm{Ti}^{+3}\right)_{2}\left(\mathrm{Ti}^{+4}\right)_{1}\left(\mathrm{O}^{-2}\right)_{5}$, this model was derived from the $\mathrm{Al}_{2} \mathrm{TiO}_{5}$ orthorhombic structure (Epicer et al. 1991), taking into account the mutual exchange of trivalent cations in one subnet, while in the other subnet occupied by $\mathrm{Ti}^{+4}$ and $\mathrm{O}^{-2}$ species there is no influence.

Subsequently, Freudenberg (1987), brings together all the data obtained and proposed a modified diagram (Fig. 2). Where the only stable compound in the $\mathrm{Al}_{2} \mathrm{O}_{3}-\mathrm{TiO}_{2}$ system is considered to be, the $\beta-\mathrm{Al}_{2} \mathrm{TiO}_{5}$ phase; this compound decomposes above $1280 \pm 1^{\circ} \mathrm{C}$ (Kato et al. 1980).

The $\mathrm{Al}_{2} \mathrm{TiO}_{5}$ divides the system in two sub-systems $\mathrm{Al}_{2} \mathrm{O}_{3}-\mathrm{Al}_{2} \mathrm{TiO}_{5}$ and $\mathrm{Al}_{2} \mathrm{TiO}_{5}-\mathrm{TiO}_{2}$ with eutectics at titania 38.5 and 80 weight percent respectively (Fig. 2).

It is important to point out the remarkable solubility difference between corundum and titania, the $\mathrm{Al}_{2} \mathrm{O}_{3}$ in $\mathrm{TiO}_{2}$ is $\approx$ one order in magnitude higher than the $\mathrm{TiO}_{2}$ in $\mathrm{Al}_{2} \mathrm{O}_{3}$, and the $\mathrm{Al}_{2} \mathrm{O}_{3}$ and $\mathrm{TiO}_{2}$ solubility are practically null in $\mathrm{Al}_{2} \mathrm{TiO}_{5}$; so it is considered aluminum titanate as a stoichiometric compound. However this claim is only correct for oxidizing atmospheres.

The $\mathrm{Al}_{2} \mathrm{O}_{3}$ has a $2.5 \%$ molar maximum solubility in $\mathrm{TiO}_{2}(1.97 \pm 0.18$ in weight $)$ at $1726^{\circ} \mathrm{C}$, (Slepetys, 1969), whereas the solubility of the latter in the alumina is almost non-existent $0.35 \%$ molar between 1300 and $1700^{\circ} \mathrm{C}$. While both oxides solubility in the $\mathrm{Al}_{2} \mathrm{TiO}_{5}$ is completely null ( Golberg, 1968). 


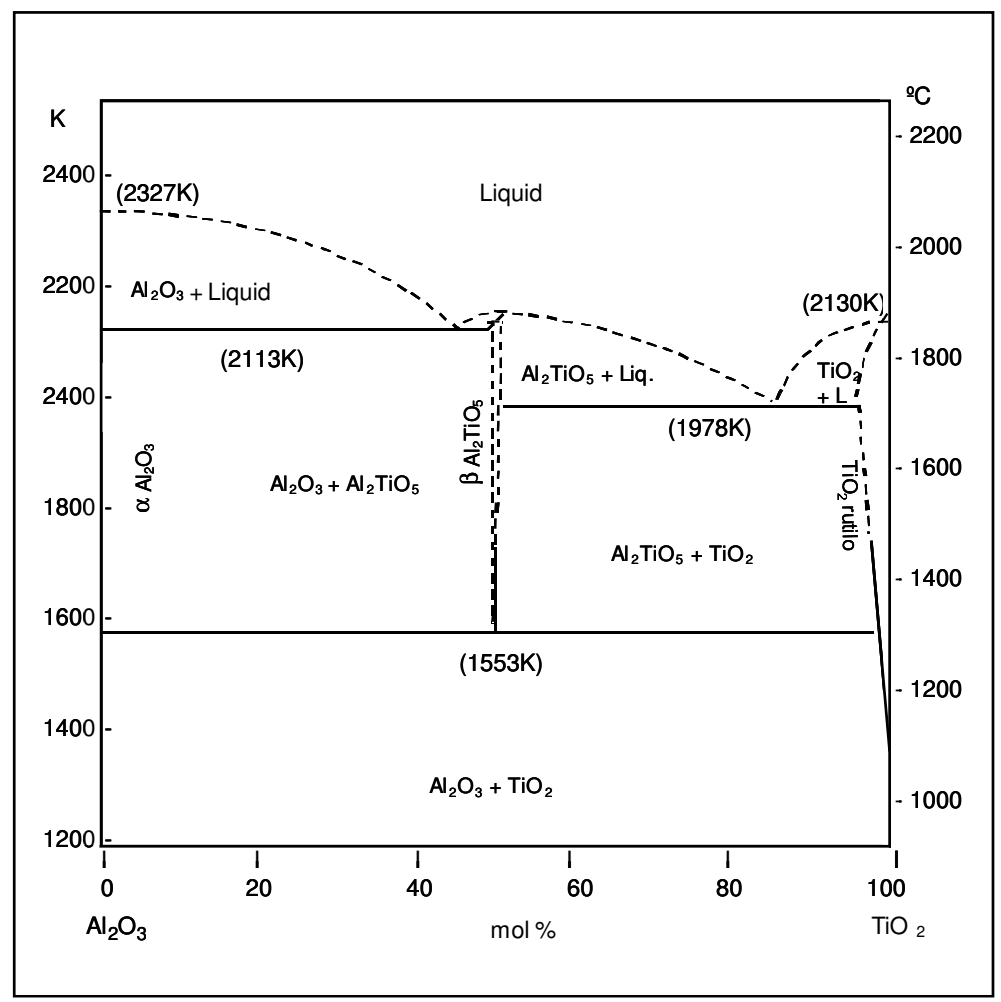

Fig. 2. $\mathrm{Al}_{2} \mathrm{O}_{3}-\mathrm{TiO}_{2}$ Equilibrium Diagram calculated in air, from experimental review by Freudenberg (1987).

\section{Additives}

The thermal instability of aluminum titanate and its low mechanical resistance are the main reasons for the additives use, taking into account these will influence the production process and the final product properties. An important characteristic for all additives is that they do not decrease significantly aluminum titanate thermomechanical properties. Small additions ( $\leq 5 \%$ by weight) are usually added with the aim of forming aluminum titanate solid solutions.

As was mentioned before, the aluminum titanate is formed above and decomposes below the equilibrium temperature $1280^{\circ} \mathrm{C}$ (Kato et al., 1980), with a free energy of formation given by:

$$
\begin{gathered}
\Delta \mathrm{G}^{\mathrm{o}} \mathrm{Al}_{2} \mathrm{TiO}_{5}=\Delta \mathrm{H}^{\mathrm{o}}-\Delta \mathrm{S}^{\mathrm{o}} \mathrm{T} \\
\Delta \mathrm{G}^{\mathrm{o}} \mathrm{Al}_{2} \mathrm{TiO}_{5}=17000-10.95 \mathrm{~T}
\end{gathered}
$$


The endothermic reaction is possible due to the entropy $\left(\Delta S^{\circ}\right)$ positive contribution. So as other pseudobrookitas, $\mathrm{Al}_{2} \mathrm{TiO}_{5}$ can be stabilized entropically (Navrotsky 1975), with certain contributions to cation disorder (Morosin et al., 1972). It is conceivable that the positive effect of entropy can be reinforced with additional entropy in terms of mixing by the formation of aluminum titanate solid solutions. It has been determined empirically that solid solutions containing $\mathrm{Fe}^{+3}$ and $\mathrm{Mg}^{+2}$, provide a lower decomposition temperature, i.e. increasing stability. On the other hand, solid solutions with $\mathrm{Cr}^{+3}$ promote a greater temperature of decomposition, i.e., reducing stability (Woermann 1985).

Jung et al. (1993), studied the replacement of $\mathrm{Ti}^{+4}$ by $\mathrm{Ge}^{+4}$ and $\mathrm{Al}^{+3}$ by $\mathrm{Ga}^{+3}$ and $\mathrm{Ge}$ solid solutions combined also with additions of $\mathrm{MgO}$ and $\mathrm{Fe}_{2} \mathrm{O}_{3}$, finding that the stabilizing effect of the additions decreased in the following order: $\mathrm{Fe}^{+3}, \mathrm{Mg}^{+2}>\mathrm{Ge}^{+2}>\mathrm{Ga}^{+3}$, corroborating data found in previous research that $\mathrm{Fe}^{+3}, \mathrm{Mg}^{+2}$ are the best stabilizers so far.

Additions such as $\mathrm{Fe}_{2} \mathrm{O}_{3}, \mathrm{MgO}$ or $\mathrm{SiO}_{2}$ were studied, the first two promoting structures of the pseudobrookites type $\mathrm{Fe}_{2} \mathrm{TiO}_{5}$ and $\mathrm{MgTi}_{2} \mathrm{O}_{5}$ giving complete solid solutions with $\mathrm{Al}_{2} \mathrm{TiO}_{5}$ (Brown 1994; Buscaglia et al., 1994; 1995; 1997). The $\mathrm{SiO}_{2}$ has limited solubility (Ishitsuka 1987), however additions up to 3 weight percent produce a slight increase in the mechanical resistance, due to small amounts of liquid phase that densify the material but, larger amounts cause excessive growth of the grain that is detrimental to the mechanical resistance, (Thomas et al., 1989).

Liu et al., (1996), studied the thermal stability of $\mathrm{Al}_{2} \mathrm{TiO}_{5}$ with $\mathrm{Fe}_{2} \mathrm{TiO}_{5}$ and $\mathrm{MgTi}_{2} \mathrm{O}_{5}$ additions finding that material with $\mathrm{Fe}^{+3}$ additions did not show any significant mechanical properties decomposition or degradation and the material with $\mathrm{Mg}^{+2}$ annealed to 1000 $1100^{\circ} \mathrm{C}$ showed an $\mathrm{Al}_{2} \mathrm{O}_{3}$ and $\mathrm{TiO}_{2}$ breakdown.

\section{Experimental procedure}

The raw materials used were reactive grade: $\mathrm{Al}_{2} \mathrm{O}_{3}\left(\mathrm{D}_{50}=0.60 \mu \mathrm{m}\right), \mathrm{TiO}_{2}\left(\mathrm{D}_{50}=0.88 \mu \mathrm{m}\right), \mathrm{V}_{2} \mathrm{O}_{5}$ $\left(\mathrm{D}_{50}=0.60 \mu \mathrm{m}\right), \mathrm{MnO}\left(\mathrm{D}_{50}=0.60 \mu \mathrm{m}\right)$, ferrosilicon $\left(\mathrm{D}_{50}=0.69 \mu \mathrm{m}\right), \mathrm{FeTiO}_{3}\left(\mathrm{D}_{50}=0.82 \mu \mathrm{m}\right)$, and, alumina ball milled $98.5 \% \mathrm{FeTiO}_{3}-1.2 \% \mathrm{SiO}_{2}$ purified mineral $\left(\mathrm{D}_{50}=0.88 \mu \mathrm{m}\right)$.

Two (2) equimolar mixtures of $\mathrm{Al}_{2} \mathrm{O}_{3}$ and $\mathrm{TiO}_{2} \quad\left(56 w t \% \mathrm{Al}_{2} \mathrm{O}_{3}-44 w t \% \mathrm{TiO}_{2}\right)$ were homogeneously mixed with 3, 6 and $9 \mathrm{wt} \%$ of each additive using alumina jars and balls, during 6 hours. No binder has been added to the aqueous media powder mixture and it was dried out at $120^{\circ} \mathrm{C}$ for 24 hours. The material was crushed in an alumina mortar prior to the manufacture of samples by uniaxial die compaction at $300 \mathrm{MPa}$. Green bodies were reactive sintered at $1450^{\circ} \mathrm{C}$, in air for $3 \mathrm{~h}$. Heating was programmed at $5^{\circ} \mathrm{C} / \mathrm{min}$. whereas cooling at $15^{\circ} \mathrm{C} / \mathrm{min}$, in order to avoid eutectoid transformation: $\mathrm{Al}_{2} \mathrm{TiO}_{5} \rightarrow \mathrm{Al}_{2} \mathrm{O}_{3}+\mathrm{TiO}_{2}$ (Kolomietsev et al.,1981).

X-ray diffraction (XRD) analysis has been performed on powders from crushed sintered samples, with grains below $30 \mu \mathrm{m}$ suitable to obtain rigid specimens. The quantification of $\mathrm{Al}_{2} \mathrm{TiO}_{5}$ formed was determined by the internal standard method, through direct determination based on the methodology of Klug and Alexander (1954). In this study, the diffraction signals used were: $\mathrm{Al}_{2} \mathrm{TiO}_{5}$ (023), $\mathrm{Al}_{2} \mathrm{O}_{3}$ (104) and $\mathrm{TiO}_{2}$ Rutile (110), which are representative of the three components of interest in the studied samples. 
Sintered sample surfaces were carefully ceramographically prepared to minimize damage and, in some cases it was needed to chemically etch in ambient $15 \% \mathrm{HF}$ solution for $60 \mathrm{~s}$, to reveal grain boundaries. The microstructure characterization was carried out using compositional back scattered electron images (BSEI) from scanning electron microscopy (SEM) and energy-dispersive X-ray spectroscopy (EDS). Evaluation of grain size and phases present has been performed by image analysis.

In order to quantify the stabilization of $\mathrm{Al}_{2} \mathrm{TiO}_{5}$, sintered samples previously thermal treated at $1100^{\circ} \mathrm{C}$ for $100 \mathrm{~h}$. were Si internal standard XRD analyzed, as in the as-sintered condition.

To determine the type of Fe ion in solution, it was used Mössbauer Spectroscopy with the isotope iron ${ }^{57} \mathrm{Fe}$, in the samples with addition of ilmenite and ferrosilicon. The source used was ${ }^{57} \mathrm{Co}$, the Mösssbauer transition is $14.41 \mathrm{keV}$, with the excited level of nuclear spin I = $3 / 2$ and fundamental level $I=1 / 2$. The extent of the isomeric shift provides information on the valence of the atom to which belong the core, as the electronic layers and therefore the density of electrons in the nucleus, are sensitive to chemical bonding.

Thermal expansion analysis in the temperature range of 25 to $1000^{\circ} \mathrm{C}$ and $1450^{\circ} \mathrm{C}$, at $5^{\circ} \mathrm{C} / \mathrm{min}$ heating and cooling ramps, has been performed on selected samples with good stabilization behavior.

\section{Discussions of results}

\subsection{Additives selection}

The additives selection is based on the cation radius, which must be related to the aluminum titanate cations i.e., $\mathrm{Al}^{+3}$ and $\mathrm{Ti}^{+4}$, in order to be able to replace them in the solid solution to be formed. The thermal expansion can be related to the degree of crystalline distortion which is known to increase with the difference between the radii of the cations.

Consequently, the octahedral distortion is much greater in $\mathrm{Al}_{2} \mathrm{TiO}_{5}$ than in $\mathrm{Fe}_{2} \mathrm{TiO}_{5}$, due to the small radius of $\mathrm{Al}^{+3}$ ions, which facilitate a tendency to the tetrahedral coordination (Bayer, G., 1973). To avoid extreme distortion, the replacing selected cations must have a radii at least close to the $\mathrm{Al}^{+3}=0.54 \AA$; i.e., $\mathrm{V}^{+5}=0.59 \AA$; $\mathrm{Mn}^{+4}=0.76 \AA$; $\mathrm{Si}^{+4}=0.41 \AA$; $\mathrm{Fe}^{+3}=0.67$ and $\mathrm{Ti}^{+4}=0.76$. Hence, all additives used in this work fulfill the requirement. On the other hand, the aluminum titanate is formed by an equimolar reaction between $\mathrm{Al}_{2} \mathrm{O}_{3}$ and $\mathrm{TiO}_{2}$. However, due to entropic reasons, in low $\mathrm{O}_{2}$ pressure conditions, as in air for example, there is a small fraction of $\mathrm{Ti}^{+3}$, its quantity being a function of the temperature. Hence, the reaction of transformation can be expressed in terms of the intermediate reaction of the titanium oxide $\mathrm{Ti}_{3} \mathrm{O}_{5}$ in the following manner:

$$
\alpha \mathrm{Al}_{2} \mathrm{O}_{3}+1 / 3 \mathrm{Ti}_{3} \mathrm{O}_{5}+1 / 6 \mathrm{O}_{2} \Leftrightarrow \mathrm{Al}_{2} \mathrm{TiO}_{5}
$$

The $\mathrm{Ti}_{3} \mathrm{O}_{5}$ can be seen in terms of $\mathrm{Ti}^{+3} \mathrm{Ti}^{+4} \mathrm{O}_{5}-2$ for which there is the possibility of forming "limited solid solutions" by cationic substitution as:

$$
(1-\mathrm{x}) \mathrm{Al}_{2} \mathrm{TiO}_{5}+x \mathrm{Ti}_{3} \mathrm{O}_{5} \Leftrightarrow\left(\mathrm{Al}^{+3}{ }_{1-\mathrm{x}} \mathrm{Ti}^{+3} \mathrm{x}\right)_{2} \mathrm{Ti}^{+4} \mathrm{O}_{5}-2
$$

Studying the affinity diagram of multivalent oxides of the transition metals with $\mathrm{O}_{2}$, it was observed that below Ti, the order of decreasing affinity with $\mathrm{O}_{2}$ is $\mathrm{V}, \mathrm{Mn}$ and Fe (Fig.3.). 


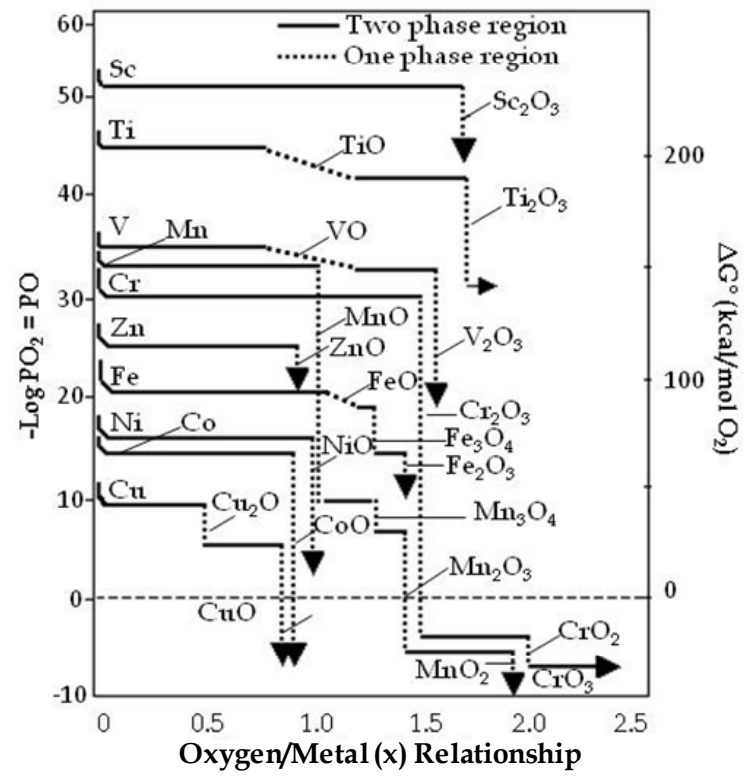

Fig. 3. Oxygen partial pressure $\left(\mathrm{PO}_{2}\right)$ vs. Oxygen/Metal ( $\mathrm{x}$ en $\mathrm{MO}_{\mathrm{x}}$ ) for the $3 \mathrm{~d}$ metals.

\subsection{Structure analysis}

The XRD results showed, for aluminum titanate without additive (Fig. 4.), that the selected temperature and time are sufficient for a near $100 \% \mathrm{Al}_{2} \mathrm{TiO}_{5}$ reaction of formation, as the most important peaks correspond to this compound with a minimum of $\mathrm{Al}_{2} \mathrm{O}_{3}$ and $\mathrm{TiO}_{2}$ remnants. It is important to point out that in all XRD, are represented the PDF values for all the constituents expected in each case, although they are not present.

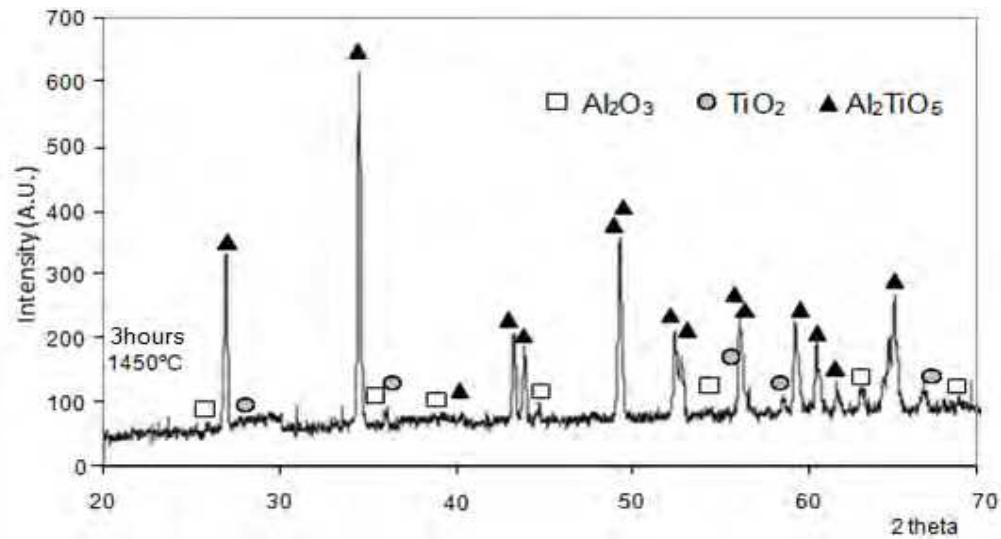

Fig. 4. X Ray Diffraction of equimolar mixture $\mathrm{Al}_{2} \mathrm{O}_{3}$ and $\mathrm{TiO}_{2}$ without addition, sintered at $1450^{\circ} \mathrm{C}$ for 3 hours. 
In the samples with $\mathrm{V}_{2} \mathrm{O}_{5}$, the formation of $\mathrm{Al}_{2} \mathrm{TiO}_{5}$ decreases as addition contents increase due to an intergranular liquid phase formed, identified by SEM-EDX, that inhibits the reaction between the main constituents (Fig. 5.)

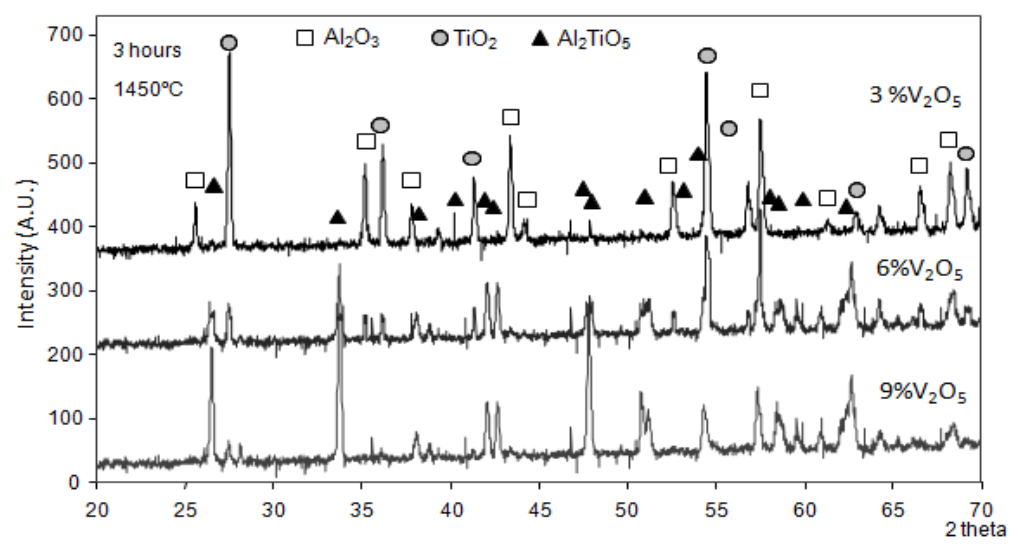

Fig. 5. X Ray Diffraction of equimolar mixture $\mathrm{Al}_{2} \mathrm{O}_{3}$ and $\mathrm{TiO}_{2}$ with $\mathrm{V}_{2} \mathrm{O}_{5}: 3,6$ and $9 \mathrm{wt} \%$ addition, sintered at $1450^{\circ} \mathrm{C}$ for 3 hours.

Regarding the $\mathrm{MnO}$ addition, it promotes $\mathrm{Al}_{2} \mathrm{TiO}_{5}$ formation with contents, as depicted by the aluminum titanate principal signals which increase in intensity whereas those of $\mathrm{Al}_{2} \mathrm{O}_{3}$ and $\mathrm{TiO}_{2}$ are suppressed. $\mathrm{MnTiO}_{3}$ appears as product of $\mathrm{TiO}_{2}$ and $\mathrm{MnO}$ eutectic reaction. (Fig. 6.).

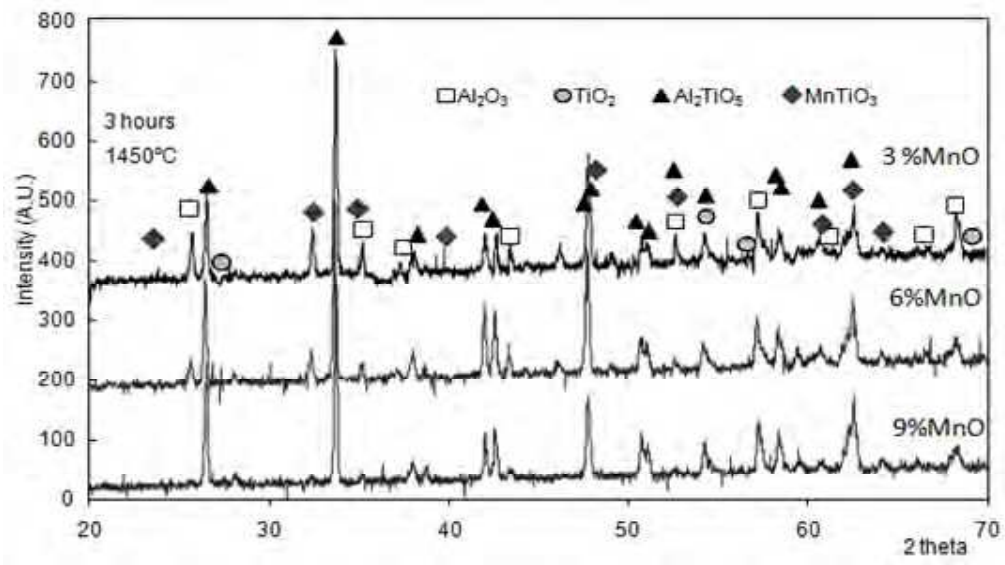

Fig. 6. X Ray Diffraction of equimolar mixture $\mathrm{Al}_{2} \mathrm{O}_{3}$ and $\mathrm{TiO}_{2}$ with $\mathrm{MnO}: 3,6$ y 9 wt $\%$ addition, sintered at $1450^{\circ} \mathrm{C}$ for 3 hours.

In the case of ferrosilicon added compositions (Fig. 7), the $\mathrm{Al}_{2} \mathrm{TiO}_{5}$ formation reaction occurs but not complete and, the main signals of $\mathrm{Al}_{2} \mathrm{O}_{3}$ and $\mathrm{TiO}_{2}$ are slightly shifted, corresponding to $\mathrm{Al}_{2} \mathrm{SiO}_{5}$ and $\mathrm{Al}_{4} \mathrm{Ti}_{2} \mathrm{SiO}_{12}$ being the latter, a product of a ternary eutectic transformation. 


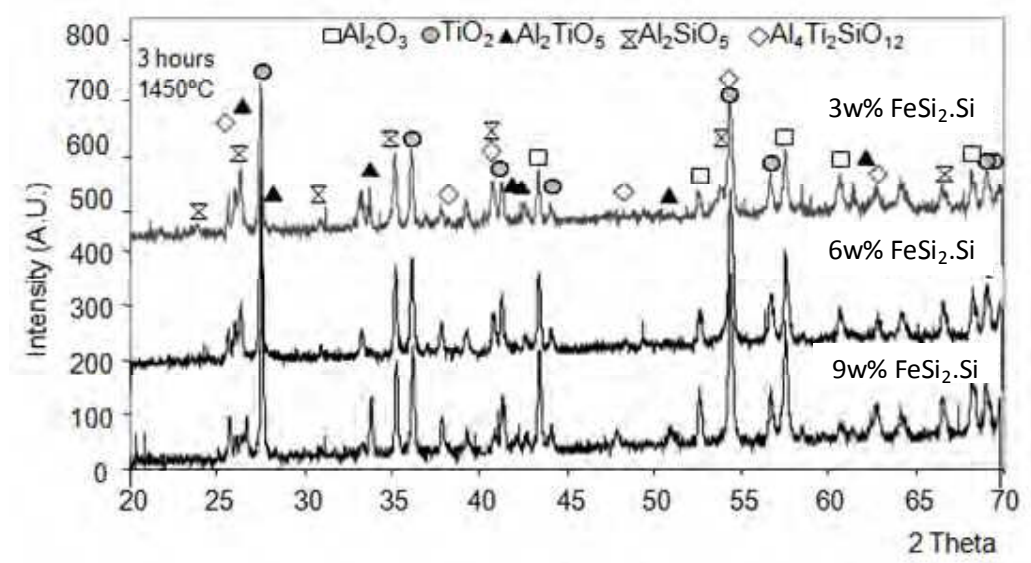

Fig. 7. $X$ Ray Diffraction of equimolar mixture $\mathrm{Al}_{2} \mathrm{O}_{3}$ and $\mathrm{TiO}_{2}$ with industrial $\mathrm{FeSi}_{2}$.Si: 3,6 and $9 \mathrm{wt} \%$ addition, sintered at $1450^{\circ} \mathrm{C}$ for 3 hours.

Both pure and concentrated mineral ilmenite $\left(\mathrm{FeTiO}_{3}\right)$ (Figs.8 and 9), promoted the formation of $\mathrm{Al}_{2} \mathrm{TiO}_{5}$ in all compositions studied. Phases such as $\mathrm{Fe}_{2} \mathrm{O}_{3}, \mathrm{TiO}_{2}$, or $\mathrm{Fe}_{2} \mathrm{TiO}_{5}$ product of decomposition and reaction of the $\mathrm{FeTiO}_{3}$, due to the oxidizing atmosphere, were not detected.

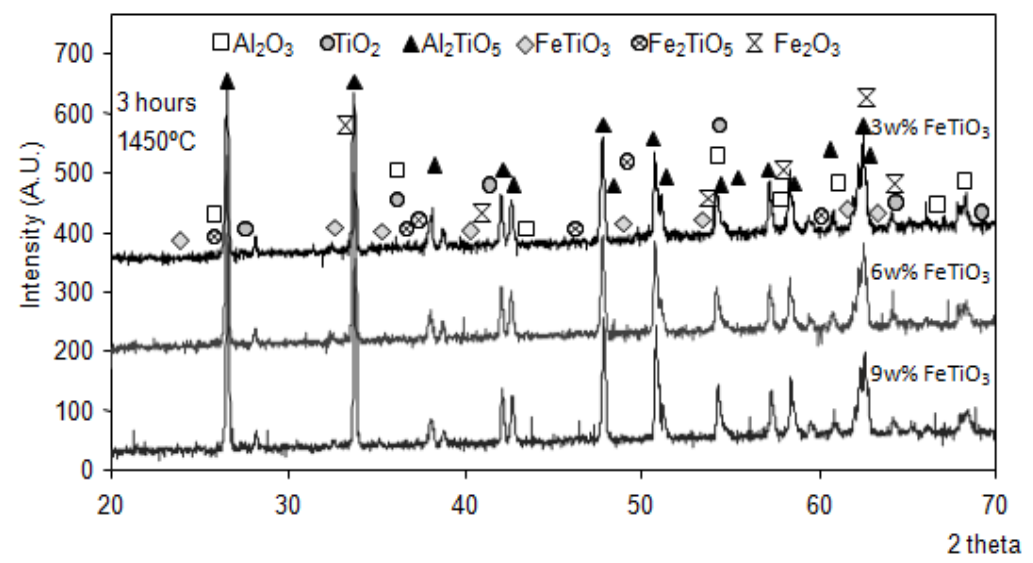

Fig. 8. X Ray Diffraction of equimolar mixture $\mathrm{Al}_{2} \mathrm{O}_{3}$ and $\mathrm{TiO}_{2}$ with pure $\mathrm{FeTiO}_{3}: 3,6$ y 9 $\mathrm{wt} \%$ addition, sintered at $1450^{\circ} \mathrm{C}$ for 3 hours.

Other remark is that expected phases, product of the reaction of contaminant $\mathrm{SiO}_{2}$ with the parent $\mathrm{Al}_{2} \mathrm{O}_{3}$ and $\mathrm{TiO}_{2}$, in the samples containing mineral did not show in the XRD spectra. Nevertheless, the most important reflections correspond to the $\mathrm{Al}_{2} \mathrm{TiO}_{5}$ corroborating the beneficial effect of this additive in its formation (Fig. 9). 


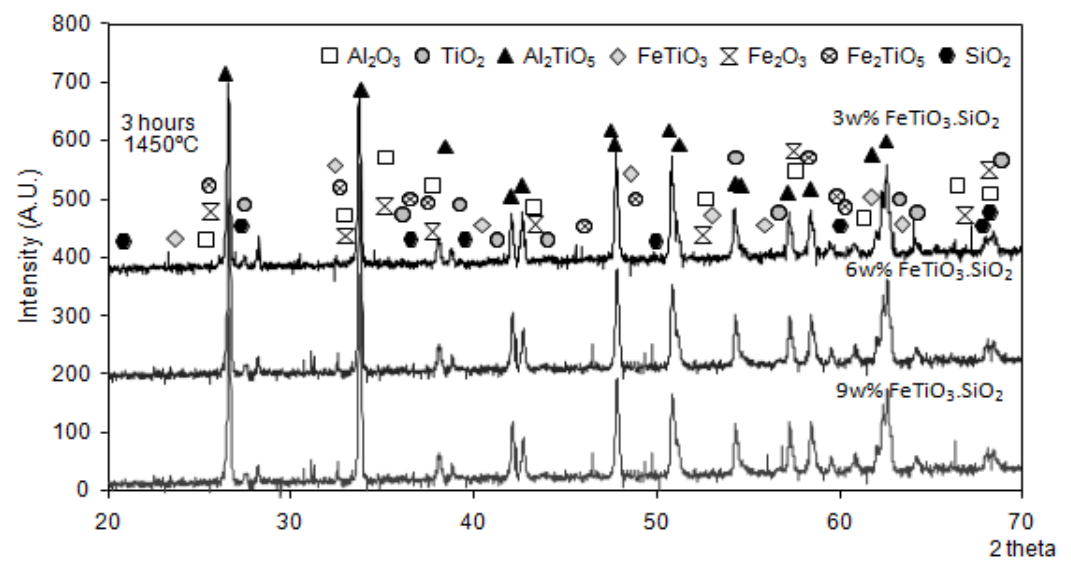

Fig. 9. $\mathrm{X}$ Ray Diffraction of equimolar mixture $\mathrm{Al}_{2} \mathrm{O}_{3}$ and $\mathrm{TiO}_{2}$ with concentrated placer ilmenite $\left(\mathrm{FeTiO}_{3} \cdot \mathrm{SiO}_{2}\right): 3,6$ and $9 \mathrm{wt} \%$ addition, sintered at $1450^{\circ} \mathrm{C}$ for 3 hours.

\subsection{1 $\mathrm{Al}_{2} \mathrm{TiO}_{5}$ formation phase quantification}

The quantification of $\mathrm{Al}_{2} \mathrm{TiO}_{5}$ formed, was determined by the internal standard method; the achieved results are showed in Table 2.

\begin{tabular}{|c|c|c|c|c|}
\hline $\mathrm{AT}+$ Additive $(\%)$ & $\%$ & $\% \mathrm{TiO}_{2}$ unreacted & $\% \mathrm{Al}_{2} \mathrm{O}_{3}$ unreacted & $\% \mathrm{Al}_{2} \mathrm{TiO}_{5}$ formed \\
\hline \multirow{3}{*}{$\mathrm{V}_{2} \mathrm{O}_{5}$} & 3 & 19.2 & 24.3 & 56.5 \\
& 6 & 20.1 & 25.5 & 54.4 \\
& 9 & 22.6 & 28.7 & 48.7 \\
\hline \multirow{3}{*}{$\mathrm{MnO}$} & 3 & 13.1 & 16.6 & 70.4 \\
& 6 & 11.2 & 14.1 & 74.7 \\
& 9 & 9.4 & 11.9 & 78.7 \\
\hline \multirow{2}{*}{$\mathrm{FeTiO}_{3} . \mathrm{SiO}_{2}$} & 3 & 5.5 & 5.8 & 88,7 \\
$(\mathrm{mineral}$ & 9 & 5.1 & 6.4 & 88.5 \\
& 3 & 5.3 & 628 & 88.5 \\
\hline \multirow{2}{*}{$\mathrm{FeTiO}_{3}$} & 6 & 1.9 & 2.7 & 95,0 \\
$(\mathrm{pure})$ & 9 & 2.3 & 2.8 & 94,8 \\
& 3 & 2.1 & 2.0 & 96,0 \\
\hline $\mathrm{FeSi}_{2}$ & 6 & 19.8 & 27.1 & 51.7 \\
& 9 & 16.9 & 25.1 & 55.1 \\
\hline
\end{tabular}

Table $2 . \mathrm{Al}_{2} \mathrm{TiO}_{5} \%$ phase formation by sintering at $1450^{\circ} \mathrm{C} / 3$ hours. 
It can be seen that the best results are obtained firstly for the pure ilmenite, secondly the mineral ilmenite, then the $\mathrm{MnO}$, vanadium oxide and ferrosilicon additions respectively.

\subsection{Microstructure analysis}

The composition without addition (Fig. 10), shows the characteristic microstructure of the aluminum titanate: a porous and microcracked $\mathrm{Al}_{2} \mathrm{TiO}_{5}$ matrix phase and the presence of unreacted $\mathrm{Al}_{2} \mathrm{O}_{3}$ and $\mathrm{TiO}_{2}$, due to the formation reaction kinetics, which is a process leaded by nucleation and growth of $\mathrm{Al}_{2} \mathrm{TiO}_{5}$ grains and finally the diffusion of the reactants remnants through the matrix, this is controlled for a very slow reacting species diffusion, as it was found by: Wohlfromm et al., (1991).

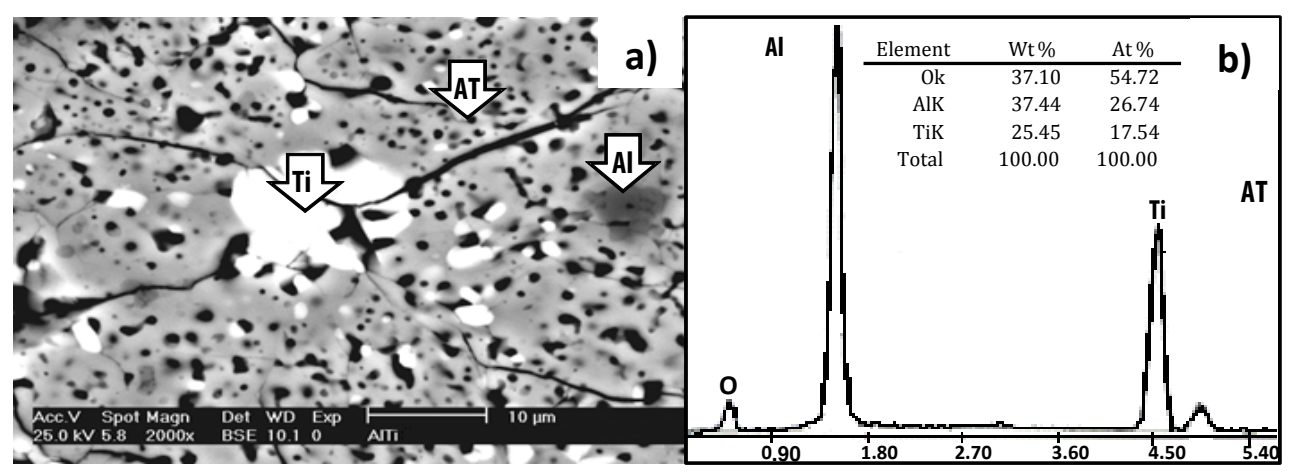

Fig. 10. a)BSE microstructure of $\mathrm{Al}_{2} \mathrm{O}_{3}$ and $\mathrm{TiO}_{2}$ without addition, sintered at $1450^{\circ} \mathrm{C}$ for 3 hours, b) EDS of the matrix with an exact atomic relationship: 25 at $\% \mathrm{Al}, 12.5$ at $\%$ Ti and 62.5 at\% O. (AT: Aluminum titanate; Ti: Titania; Al: Alumina).

The addition of the low melting point $\mathrm{V}_{2} \mathrm{O}_{5}\left(678^{\circ} \mathrm{C}\right)$ is evidenced in the microstructure with the presence of an abundant glassy intergranular phase, which constitutes a physical barrier between $\mathrm{Al}_{2} \mathrm{O}_{3}$ and $\mathrm{TiO}_{2}$, retarding the $\mathrm{Al}_{2} \mathrm{TiO}_{5}$ formation (Fig. 11a).

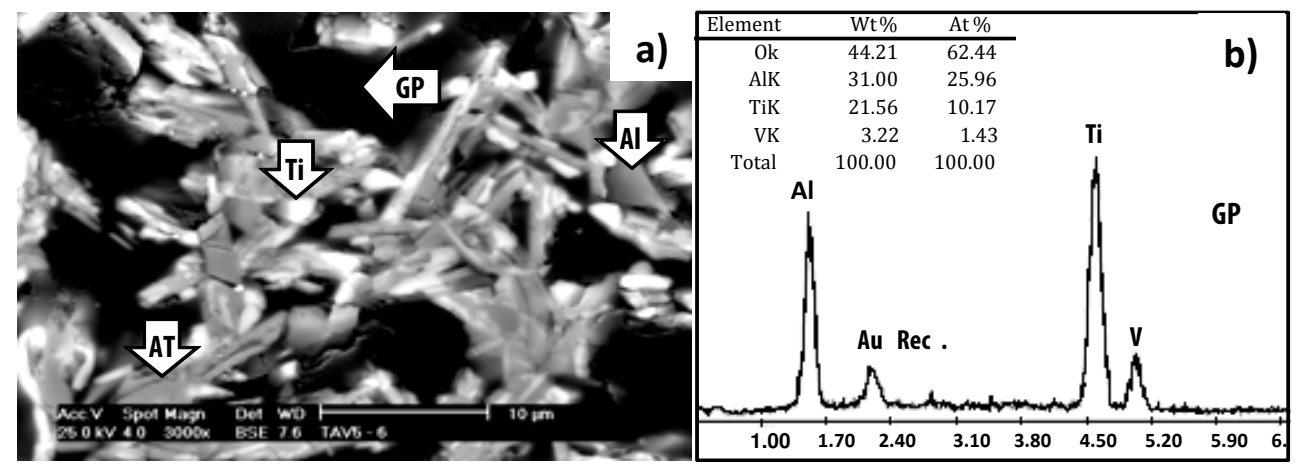

Fig. 11. a)BSE microstructure detail of $\mathrm{Al}_{2} \mathrm{O}_{3}$ and $\mathrm{TiO}_{2}$ with $\mathrm{V}_{2} \mathrm{O}_{5}: 6 \mathrm{wt} \%$ addition, sintered at $1450^{\circ} \mathrm{C}$ for 3 hours. b) EDS of the intergranular glassy phase (GP), appearing due to $\mathrm{V}_{2} \mathrm{O}_{5}$ low melting point. (AT: Aluminum titanate; Ti: Titania; Al: Alumina). 
Althought localized EDS analysis on the glassy phase was carried out, the $\mathrm{Al}$ and $\mathrm{Ti}$ values obtained are due to the larger electron beam action volume compared to phase size (Fig. 11b).

The microstructure of $\mathrm{MnO}$ added samples shows extensive $\mathrm{Al}_{2} \mathrm{TiO}_{5}$ phase formation, with a minor presence of liquid phase, product of the two eutectic reactions, at $1290^{\circ} \mathrm{C}$ and $1330^{\circ} \mathrm{C}$, between $\mathrm{MnO}$ and $\mathrm{TiO}_{2}$. However, opposite to the $\mathrm{V}_{2} \mathrm{O}_{5}$ added samples, the reacting species diffusion and $\mathrm{Al}_{2} \mathrm{TiO}_{5}$ formation is accelerated with the $\mathrm{MnO}$ contents and, unreacted $\mathrm{TiO}_{2}$ is absent in the microstructure, due to the secondary reactions. EDS analysis identified the intergranular eutectic phase as $2 \mathrm{MnO}^{\mathrm{TiO}}{ }_{2}$ and $\mathrm{MnO}^{\mathrm{TiO}}{ }_{2}$ (Fig. 12). Microstructure grain size decreased with $\mathrm{MnO}$ contents in the sintered bodies.

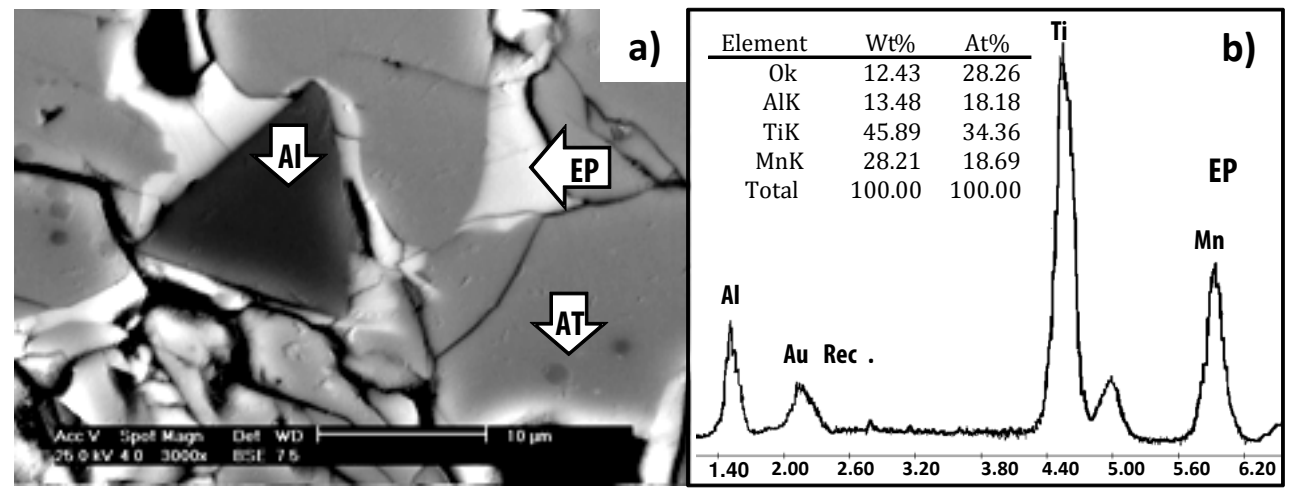

Fig. 12. a)BSE microstructural detail of $\mathrm{Al}_{2} \mathrm{O}_{3}$ and $\mathrm{TiO}_{2}$ with $\mathrm{MnO}: 6 \mathrm{wt} \%$ addition, sintered at $1450^{\circ} \mathrm{C}$ for 3 hours. b) EDS of the intergranular $\mathrm{MnTiO}_{3}$ eutectic phase (EP).

(AT: Aluminum titanate; Al: Alumina).

The $\mathrm{FeSi}_{2} . \mathrm{Si}$ modified composition has a different microstructure to that obtained with other additives (Fig.13a-d).

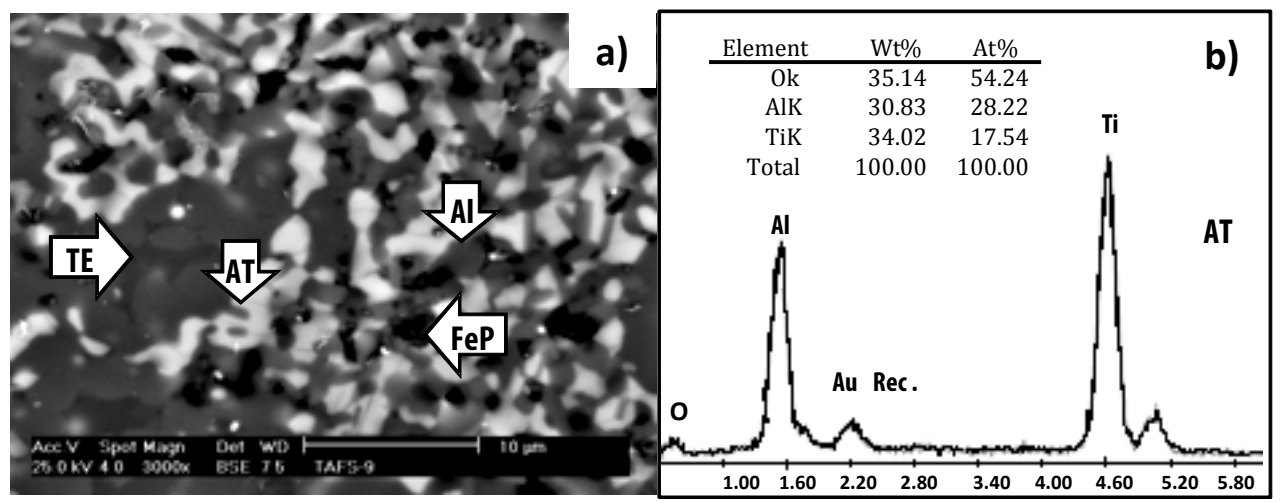

Fig. 13. a) BSE microstructural detail of $\mathrm{Al}_{2} \mathrm{O}_{3}$ and $\mathrm{TiO}_{2}$ with $\mathrm{FeSi}_{2} \cdot \mathrm{Si}$ : $6 \mathrm{wt} \%$ addition, sintered at $1450^{\circ} \mathrm{C}$ for 3 hours. b)EDS of the $\mathrm{A} 12 \mathrm{TiO} 5$ matrix. 


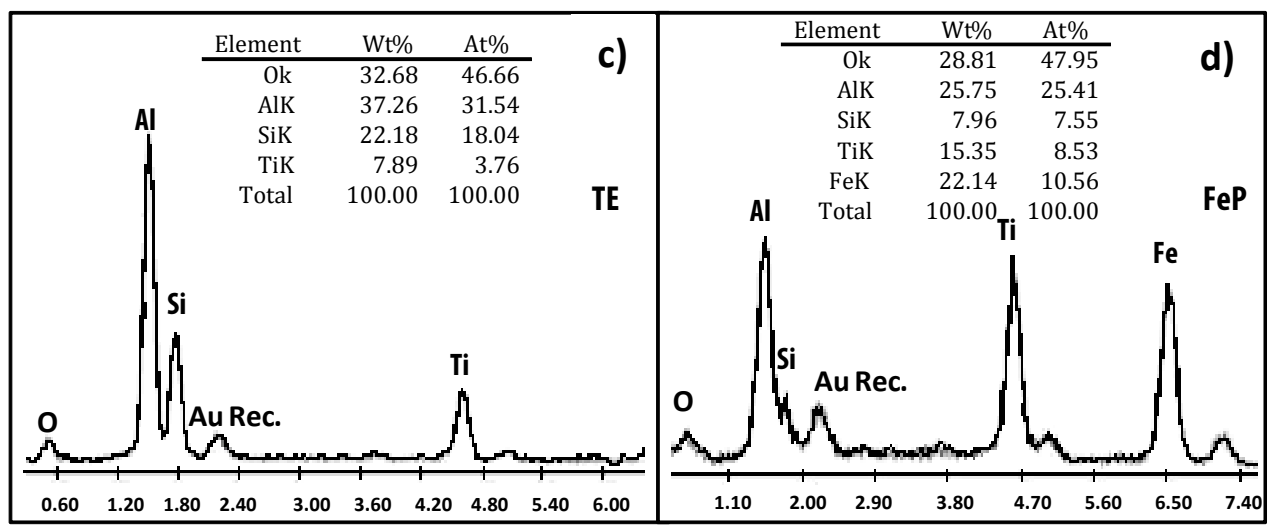

Fig. 13. c) EDS of ternary eutectic (TE) and d) EDS of the intergranular Fe rich phase (FeP).

A fraction of free $\mathrm{Al}_{2} \mathrm{O}_{3}$ remains as an intragranular phase, the $\mathrm{TiO}_{2}$ reacts completely and besides the $\mathrm{Al}_{2} \mathrm{TiO}_{5}$ matrix phase a ternary eutectic reaction grainy phase is formed between the $\mathrm{Al}_{2} \mathrm{O}_{3}-\mathrm{SiO}_{2}-\mathrm{TiO}_{2}$ (as low as it is undetected by $\mathrm{RXD}$ ), but increasing its quantity with the additive and, also a fourth intergranular phase rich in Fe is depicted (Fig.13d) (Arenas et al. 2011).

Pure and concentrated ilmenite $\left(\mathrm{FeTiO}_{3}\right)$, additions have a beneficial effect on grain growth control (Fig. 14 and 15). The $\mathrm{SiO}_{2}$ left in the purified mineral promoted the formation of an intergranular liquid phase which could not be detected by XRD. Microstructures are practically free of unreacted original phases.

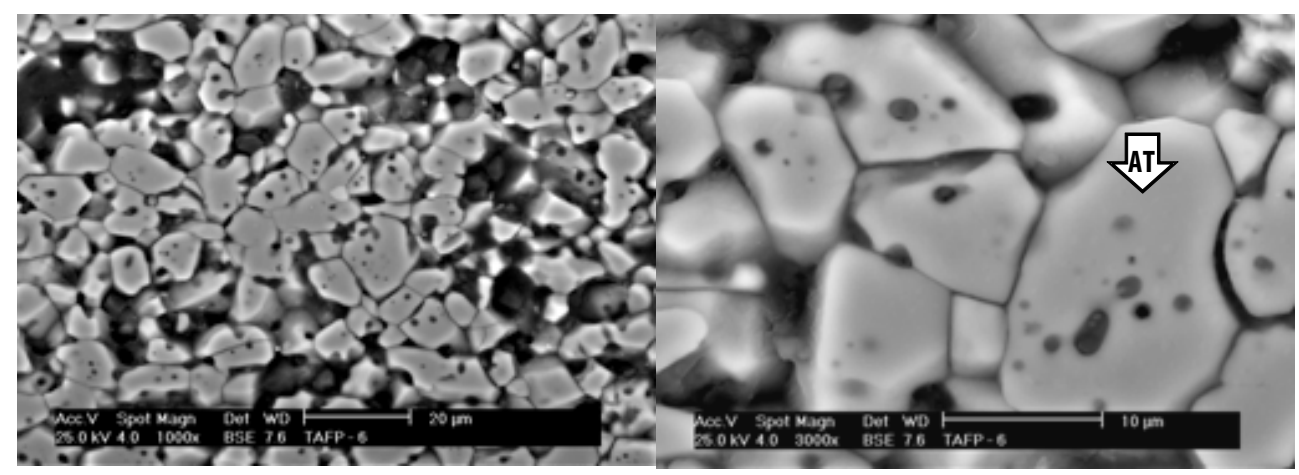

Fig. 14. a) BSE microstructural $\times 1000$ and a detail $\mathrm{X} 3000$, of $\mathrm{Al}_{2} \mathrm{O}_{3}$ and $\mathrm{TiO}_{2}$ with pure $\mathrm{FeTiO}_{3}: 6 \mathrm{wt} \%$ addition, sintered at $1450^{\circ} \mathrm{C}$ for 3 hours. Notice the grain growth control. 


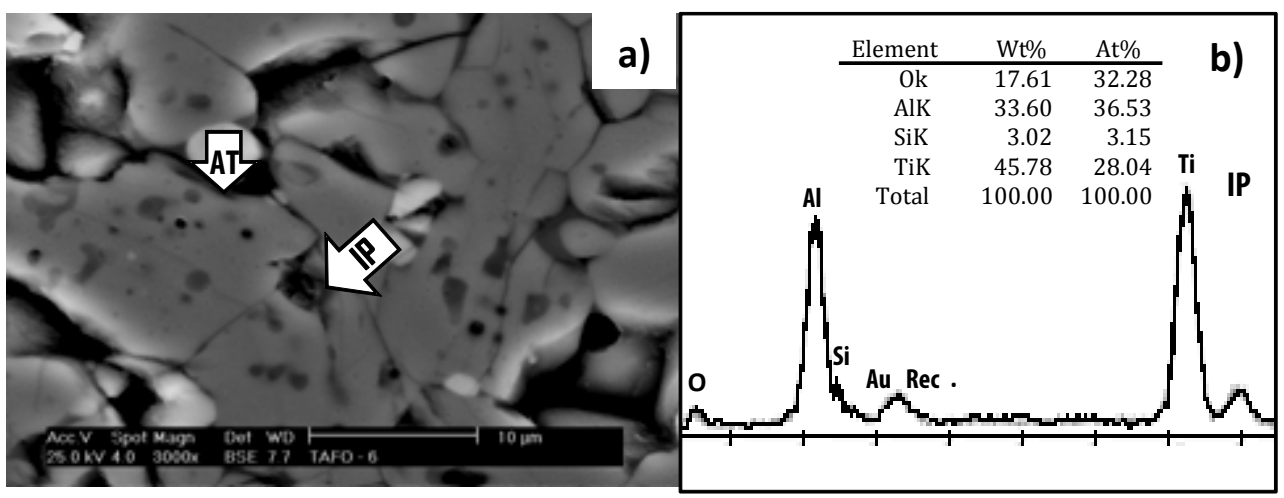

Fig. 15. a) BSE microstructural detail $\mathrm{X} 3000$, of $\mathrm{Al}_{2} \mathrm{O}_{3}$ and $\mathrm{TiO}_{2}$ with with concentrated placer ilmenite $\left(\mathrm{FeTiO}_{3} . \mathrm{SiO}_{2}\right): 6 \mathrm{wt} \%$ addition, sintered at $1450^{\circ} \mathrm{C}$ for 3 hours. b) EDS of intergranular phase due to $\mathrm{SiO}_{2}$ presence.

\subsection{Thermal stability}

In order to determine the compositions stability, XRD analyses were performed on samples heat treated at $1100^{\circ} \mathrm{C}$ for 100 hours. The temperature selection is based on industrial applications working conditions and the maximum temperature for decomposition to occur.

The samples without additives and those with $\mathrm{V}_{2} \mathrm{O}_{5}$ and $\mathrm{MnO}$ showed a complete decomposition after heat treatment, as only the diffraction peaks of $\mathrm{Al}_{2} \mathrm{O}_{3}$ and $\mathrm{TiO}_{2}$ were showed. (Fig. 16).

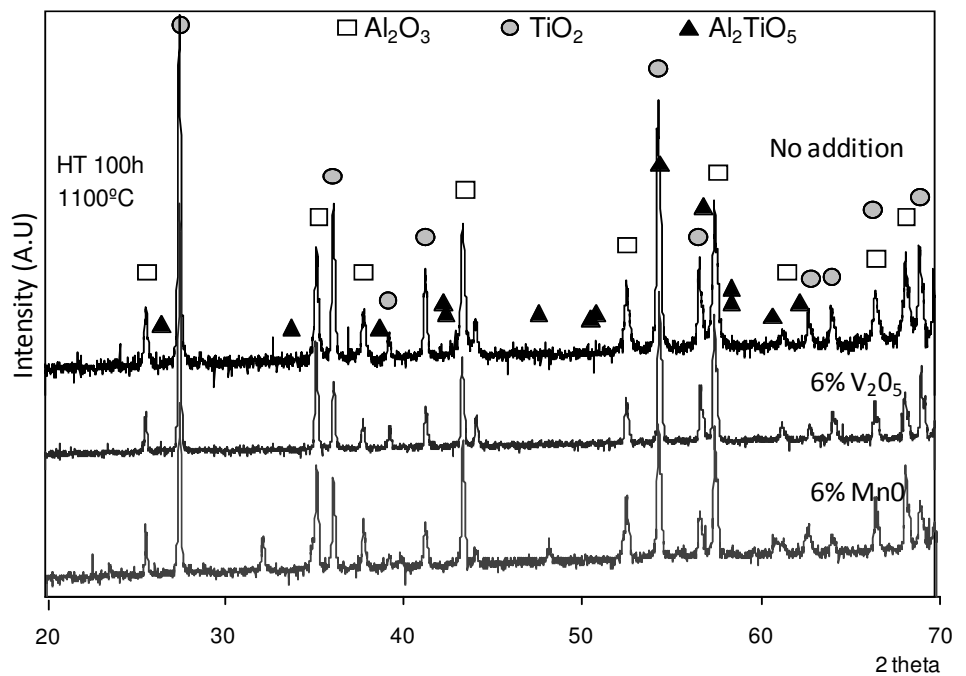

Fig. 16. $\mathrm{X}$ Ray Diffraction $\mathrm{Al}_{2} \mathrm{TiO}_{5}$ without addition, with $6 \mathrm{wt} \% \mathrm{~V}_{2} \mathrm{O}_{5}$ and $6 \mathrm{wt} \% \mathrm{MnO}$, heat treated for 100 hours at $1100^{\circ} \mathrm{C}$. 
For $\mathrm{FeSi}_{2}$.Si added samples (Fig.17), although the presence of oxidizing atmosphere, leads to the oxidation of $\mathrm{Si}$ and subsequent formation of ternary liquid phase between $\mathrm{Al}_{2} \mathrm{O}_{3}, \mathrm{TiO}_{2}$ and $\mathrm{SiO}_{2}$ which promotes a good densification, it has a minimal beneficial effect on stabilization. The presence of $\mathrm{Al}_{2} \mathrm{TiO}_{5}$ diffraction peaks is small if compared with that of $\mathrm{Al}_{2} \mathrm{O}_{3}$ and $\mathrm{TiO}_{2}$, product of decomposition. It might be explained as, that only a fraction of the $\mathrm{Fe}$ ions from the $\mathrm{FeSi}_{2}$ react and substitute the $\mathrm{Al}^{+3}$ ions, stabilizing the material.

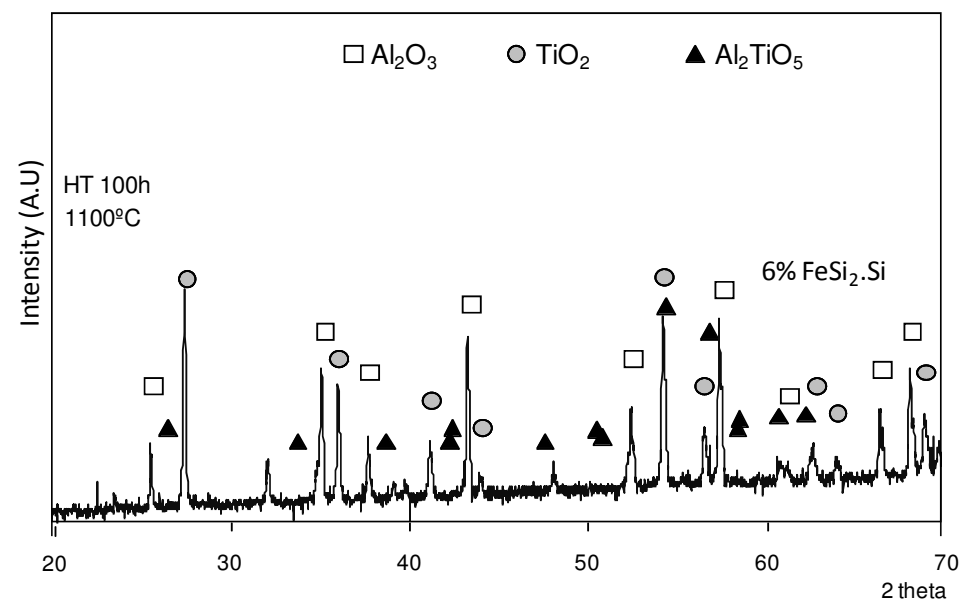

Fig. 17. X Ray Diffraction of $\mathrm{Al}_{2} \mathrm{TiO}_{5}$ with $\mathrm{FeSi}_{2} . \mathrm{Si} 6 \mathrm{wt} \%$ addition, heat treated for 100 hours at $1100^{\circ} \mathrm{C}$.

The addition of pure $\mathrm{FeTiO}_{3}$ (ilmenite) clearly shows an increase in the aluminum titanate stabilization (Fig. 18).

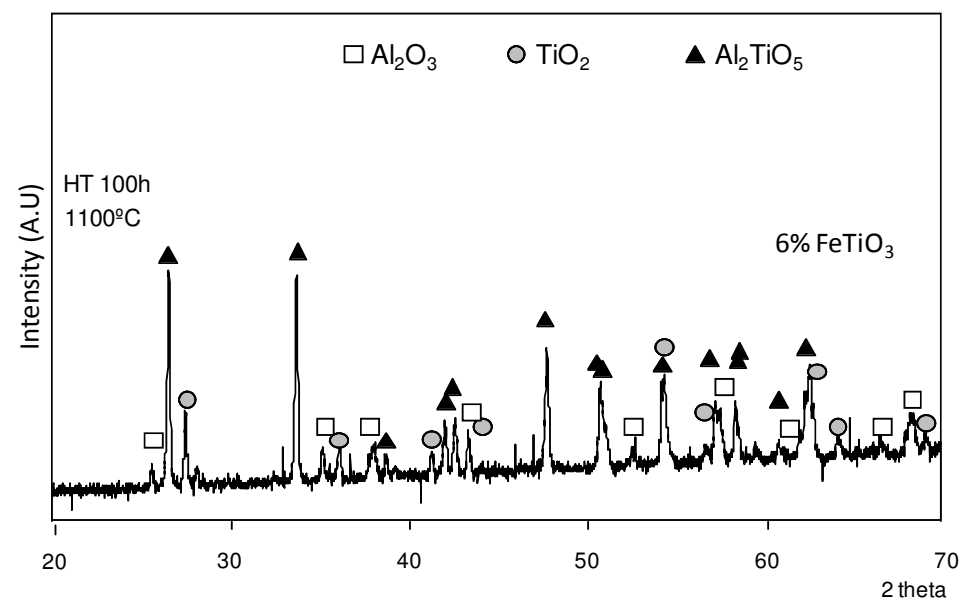

Fig. 18. X Ray Diffraction of $\mathrm{Al}_{2} \mathrm{TiO}_{5}$ with $\mathrm{FeTiO}_{3} 6 \mathrm{wt} \%$ addition, heat treated for 100 hours at $1100^{\circ} \mathrm{C}$. 
This behavior agrees with the expected solid solution formation between $\mathrm{FeTiO}_{3}$ and $\mathrm{Al}_{2} \mathrm{TiO}_{5}$, as depicted in the calorimetric studies (DSC). These experiments show the decomposition of ilmenite in air atmosphere to $\mathrm{Fe}_{2} \mathrm{O}_{3}$ and $\mathrm{TiO}_{2}$ with the formation of $\mathrm{Fe}_{2} \mathrm{TiO}_{5}$ (Suresh et al.,1991), followed by $\mathrm{Al}_{2} \mathrm{TiO}_{5}$ reaction at higher temperature. This allows the possibility of a solid solution formation between $\mathrm{Al}_{2} \mathrm{TiO}_{5}$ and the isostructural $\mathrm{Fe}_{2} \mathrm{TiO}_{5}$ by a cation replacement mechanism.

From the ionic radii concept, the structural stabilization might be explained by the incorporation of $\mathrm{Fe}^{+3}(\mathrm{r}=0.67 \AA)$ which decreases the structure distortion, caused by the $\mathrm{Ti}^{+} 4$ : $\mathrm{Al}^{+} 3$ radii difference (Shannon, $\left.\mathrm{R} ., 1969\right)$.

In the case of ilmenite addition, but from the concentrated mineral (Fig.19), the structural stabilization effect is evidenced only for the composition with $9 \%$ addition. This behavior might be attributed to the $\mathrm{SiO}_{2}$ contamination which, on the other hand, benefits body densification by a liquid phase sintering mechanism.

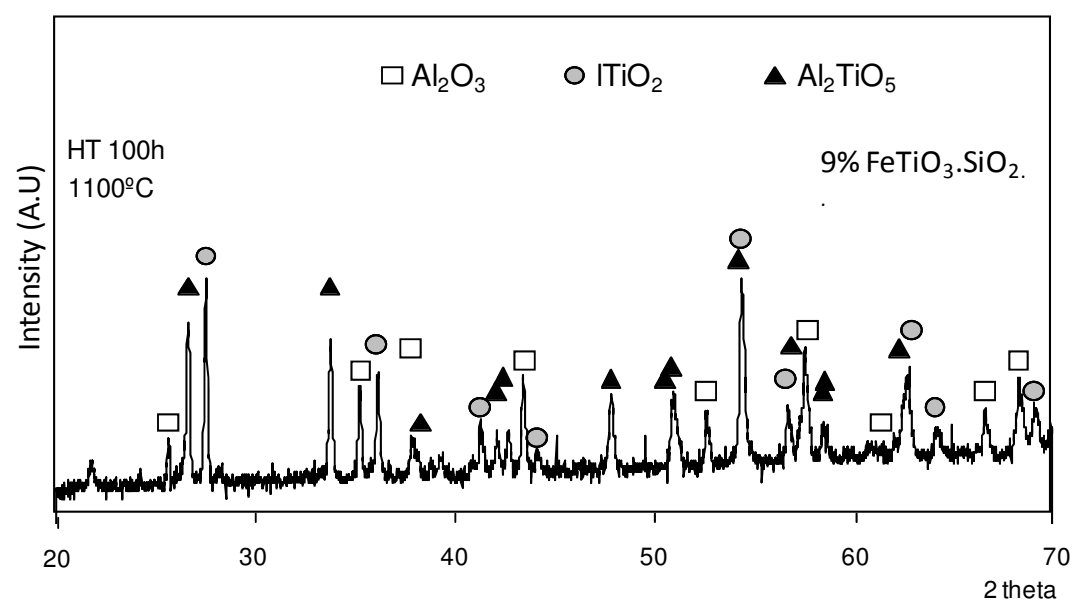

Fig. 19. $\mathrm{X}$ Ray Diffraction of $\mathrm{Al}_{2} \mathrm{TiO}_{5}$ with $\mathrm{FeTiO}_{3} \cdot \mathrm{SiO}_{2} 9 \mathrm{wt} \%$ addition, heat treated for 100 hours at $1100^{\circ} \mathrm{C}$.

The microstructure study by SEM-EDS corroborated the X-ray analysis evaluation (Fig. 20). All heat treated samples showed the characteristic elongated grain shape, typical of the $\mathrm{Al}_{2} \mathrm{TiO}_{5}$ decomposition into its original precursors raw materials $\mathrm{Al}_{2} \mathrm{O}_{3}$ and $\mathrm{TiO}_{2}$. However, stabilized $\mathrm{Al}_{2} \mathrm{TiO}_{5}$ phase is observed in the compositions with $6 \%$ pure ilmenite, $9 \%$ concentrated mineral and in lower proportion in the samples with $6 \%$ ferrosilicon. 


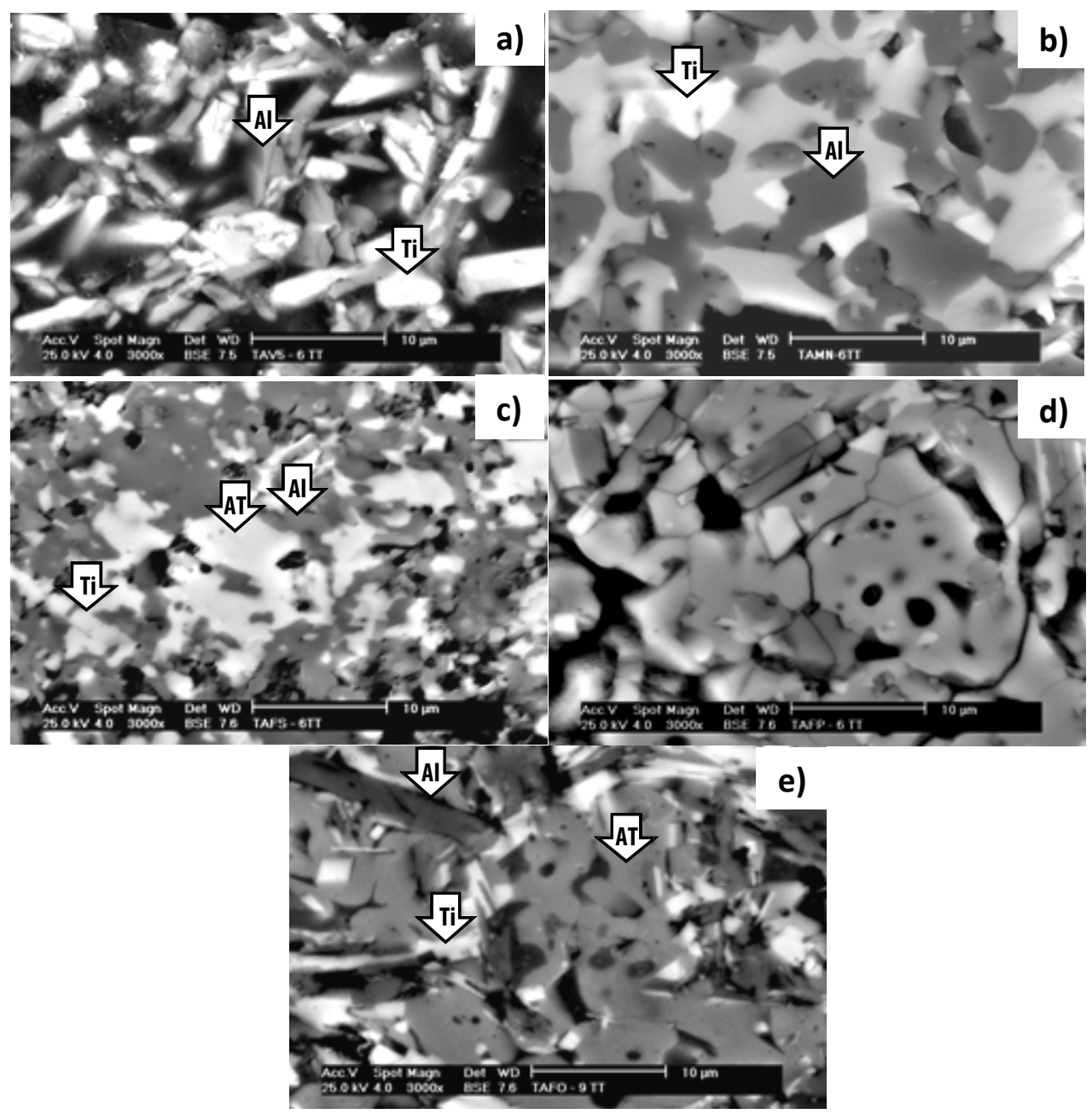

Fig. 20. a) BSE Microstructural detail x3000, $\mathrm{Al}_{2} \mathrm{TiO}_{5}$ with : a) $\mathrm{V}_{2} \mathrm{O}_{5} 6 \mathrm{wt} \%$; b) $\mathrm{MnO} 6 \mathrm{wt} \%$; c) $\mathrm{FeSi}_{2} \cdot \mathrm{SiO}_{2} 6 \mathrm{wt} \%$ d) $\mathrm{FeTiO}_{3} 6 \mathrm{wt} \%$ and e) $\mathrm{FeTiO}_{3} \cdot \mathrm{SiO}_{2} 9 \mathrm{wt} \%$ addition, heat treated at $1100^{\circ} \mathrm{C}$ for 100 hours. (AT: Aluminum titanate; Ti: Titania; Al: Alumina).

\section{5 $\mathrm{Al}_{2} \mathrm{TiO}_{5}$ decomposition phase quantification}

The quantification of $\mathrm{Al}_{2} \mathrm{TiO}_{5}$ decomposed after heat treatment was also determined using the internal standard method being the results showed in Table 3. The values obtained corroborate BSE image analysis, observations. The stabilization addition effect being higher in the compositions with pure and concentrated mineral, the $\mathrm{MnO}$ and the ferrosilicon stabilize slightly while vanadium oxide have not any effect. 


\begin{tabular}{|c|c|c|c|c|}
\hline AT+Additive (\%) & $\%$ & $\% \mathrm{TiO}_{2}$ decomposed & $\% \mathrm{Al}_{2} \mathrm{O}_{3}$ decomposed & $\% \mathrm{Al}_{2} \mathrm{TiO}_{5}$ left \\
\hline \multirow{3}{*}{$\mathrm{V}_{2} \mathrm{O}_{5}$} & 3 & 43.86 & 55.82 & 0.32 \\
& 6 & 43.29 & 55.10 & 1.61 \\
& 9 & 43.71 & 55.63 & 0.66 \\
\hline \multirow{3}{*}{$\mathrm{MnO}$} & 3 & 35.69 & 45.41 & 18.90 \\
& 6 & 32.40 & 41.22 & 26.38 \\
& 9 & 32.90 & 41.84 & 25.26 \\
\hline \multirow{3}{*}{$\mathrm{FeTiO}_{3} . \mathrm{SiO}_{2}$} & 3 & 26.53 & 26.97 & 46.50 \\
& 9 & 23.06 & 29.30 & 47,64 \\
& 3 & 23.10 & 30.12 & 48.78 \\
\hline & 6 & 17.17 & 21.78 & 61.05 \\
$\mathrm{FeTiO}_{3}$ & 9 & 10.28 & 13.01 & 76.71 \\
& 3 & 8.65 & 10.93 & 80.42 \\
\hline & 6 & 38.01 & 48.36 & 13.63 \\
$\mathrm{FeSi}_{2}$ & 9 & 36.26 & 46.13 & 17.61 \\
& 3 & 33.20 & 42.24 & 24.56 \\
\hline
\end{tabular}

Table $3 . \mathrm{Al}_{2} \mathrm{TiO}_{5} \%$ Phase decomposition after heat treatment at $1100^{\circ} \mathrm{C} / 100$ hours, by internal standard quantification method.

\subsection{Grain size}

Since the best stabilyzing behaviour after heat treatment was achieved by the ilmenites addition, these samples in the as sintered condition, were selected to determine the effect of additive contens on grains size. There were no significant variations in the grain size obtained with the two additives; however, there is a slight decrease in size as the percentage of the additive increases (in both cases), determined by image analysis of grain size (Table 4). The grain size varies between 9 and $12 \mu \mathrm{m}$. In other words, the presence of second phase slightly inhibits the growth of grain.

\begin{tabular}{|c|c|c|c|}
\hline $\mathrm{FeTiO}_{3}(\%)$ & $\mathrm{Tg}(\mu \mathrm{m})$ & $\mathrm{FeTiO}_{3} . \mathrm{SiO}_{2}(\%)$ & $\mathrm{Tg}(\mu \mathrm{m})$ \\
\hline 3 & 11.96 & 3 & 11.18 \\
\hline 6 & 11.60 & 6 & 10.52 \\
\hline 9 & 9.18 & 9 & 9,31 \\
\hline
\end{tabular}

Table 4. Effect of $\mathrm{FeTiO}_{3}$ (pure and concentrated mineral) on the grain size of sintered samples at $1450^{\circ} \mathrm{C} / 3$ hours. 


\subsection{Mössbauer spectroscopy}

It has confirmed the presence of the $\mathrm{Fe}^{+3}$ ions in all compositions with $\mathrm{Fe}$ added, i.e., the ilmenites and ferrosilicon.

The Mössbauer spectrum for material with $6 \%$ of ferrosilicon addition can be adjusted to two doublets (Fig.21a). The first doublet corresponds to the ferrous cation $\left(\mathrm{Fe}^{+2}\right)$ with a resonance that fits the hyperfine splitting with an isomer shift: IS $=1.01 \pm 0.002 \mathrm{~mm} / \mathrm{s}$ and a quadrupole splitting: QS $=0.664 \pm 0.003 \mathrm{~mm} / \mathrm{s}$. The second doublet corresponds to the resonance of the ferric cation $\left(\mathrm{Fe}^{+3}\right)$ with a IS $=0.323 \pm 0.003 \mathrm{~mm} / \mathrm{s}$ and a $\mathrm{QS}=0.520 \pm 0.004$ $\mathrm{mm} / \mathrm{s}$. For composition with $6 \%$ pure ilmenite addition (Fig. 21b.), it is revealed a consistent doublet with the ferric state $\left(\mathrm{Fe}^{+3}\right)$, with a IS $=0.323+0.003 \mathrm{~mm} / \mathrm{s}$ and QS $=0.520 \pm 0.004$ $\mathrm{mm} / \mathrm{s}$. The spectrum for the sample with $6 \%$ of mineral ilmenite (Fig. 19c), one could guess the doublet corresponds to both states ferrous $\left(\mathrm{Fe}^{+2}\right)$ and ferric $\left(\mathrm{Fe}^{+3}\right)$, however should be noted that results are not accurate, with considerable dispersion.
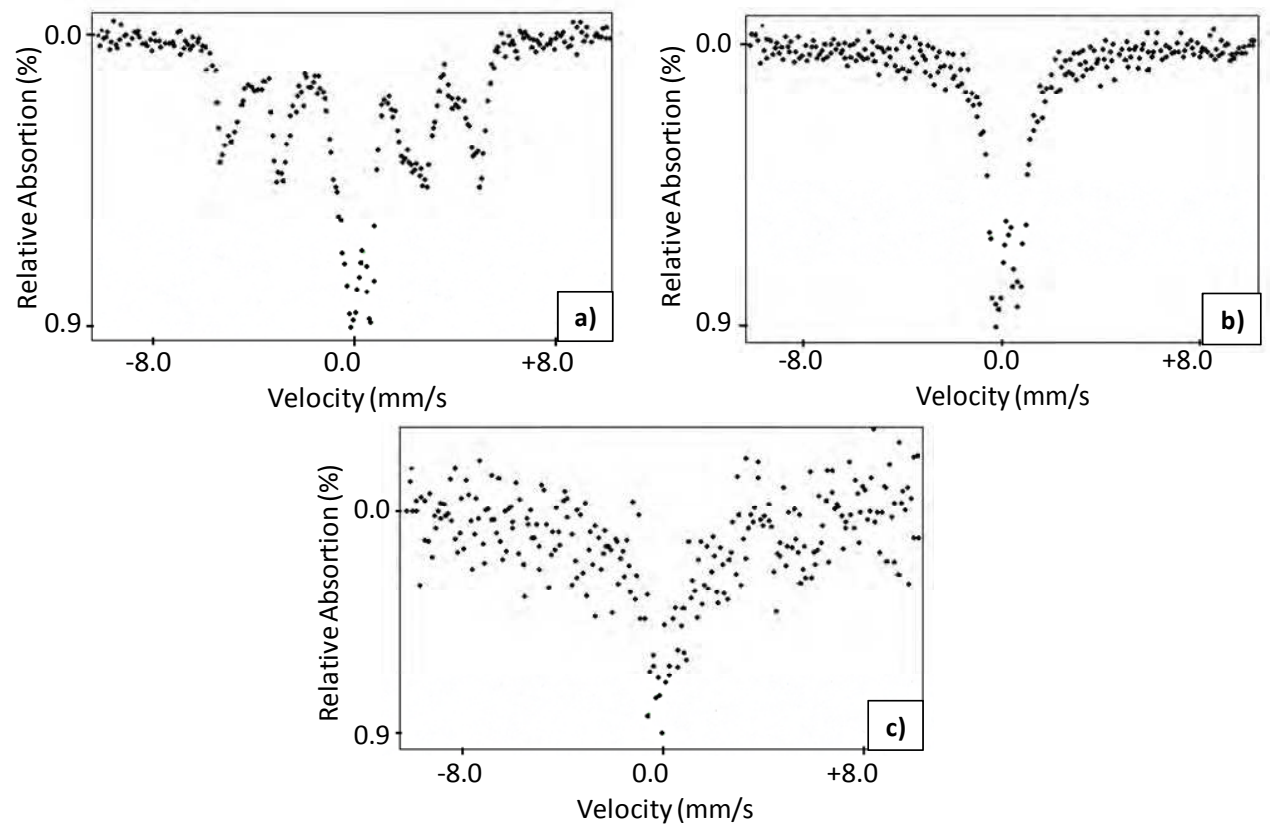

Fig. 21. Mössbauer Spectroscopy of $\mathrm{Al}_{2} \mathrm{TiO}_{5}$ with: a) $6 \mathrm{wt} \% \mathrm{FeSi}_{2} \cdot \mathrm{SiO}_{2}$; b) $6 \mathrm{wt} \% \mathrm{FeTiO}_{3}$ and c) $6 \mathrm{wt} \% \mathrm{FeTiO}_{3} \cdot \mathrm{SiO}_{2}$ additions.

These results corroborate the possible replacement of the $\mathrm{Al}^{+3}$ ions by ion $\mathrm{Fe}^{+3}$; there is higher stabilization in samples with pure ilmenite addition, where all Fe ions are in ferric state. However, as it was found in previous research (Barrios de Arenas \& Cho, 2010), the presence of $\mathrm{Fe}^{+2}$ ions, also represent the possibility of $\mathrm{Al}^{+3}$ ions substitution, with the creation of defects, which in turn promotes the diffusion in solid state. 


\subsection{Thermal expansion}

Some authors have directly related the area of hysteresis in thermal expansion curves to sample microcracks density (Lingenberg W. 1985). In this study, after comparison of the ilmenite added and pure $\mathrm{Al}_{2} \mathrm{TiO}_{5}$ materials results (Fig.22), show an evident reduction in the area of hysteresis in the formers, being even more important in the samples with concentrated mineral $\mathrm{FeTiO}_{3}$ addition (fig.22 b).

In both $\mathrm{FeTiO}_{3}$-added samples, the property values are antagonist to addition contents.

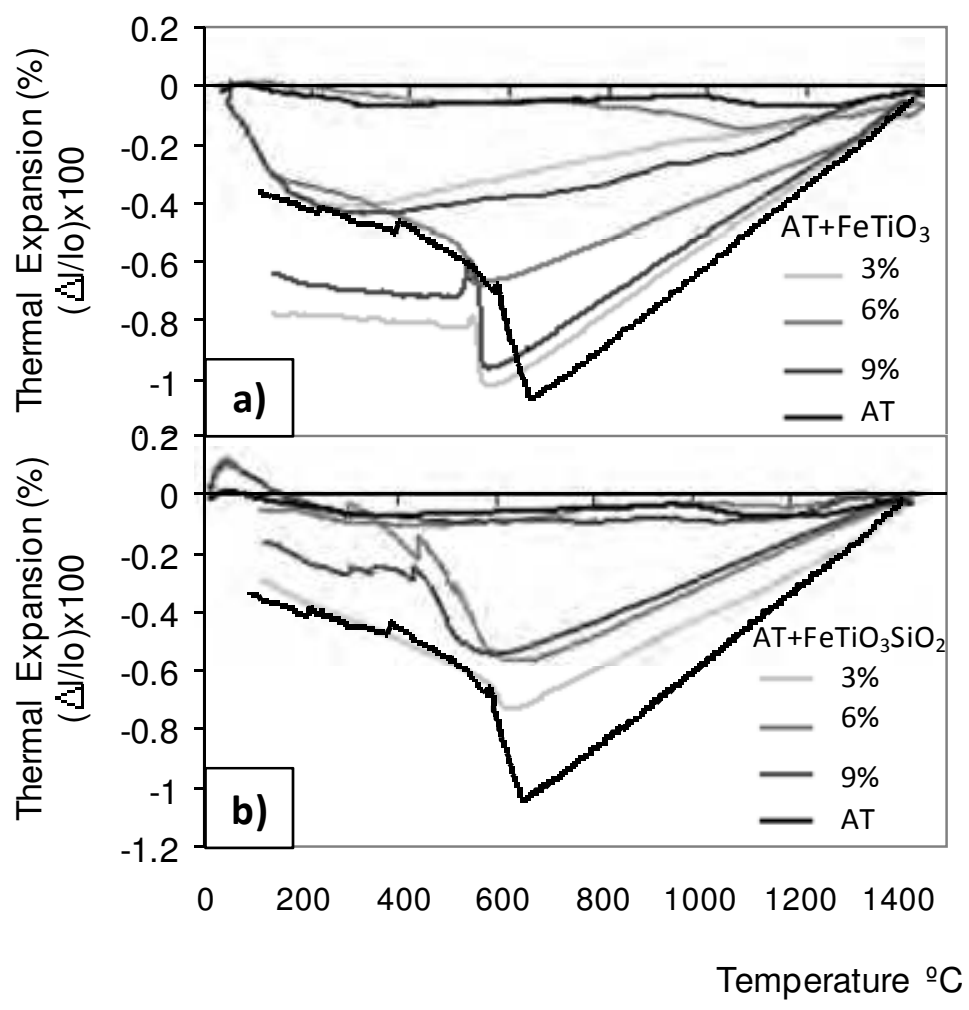

Fig. 22. Thermal Expansion betweeen $20-1450^{\circ} \mathrm{C}$ of $\mathrm{Al}_{2} \mathrm{TiO}_{5}$ with a) $\mathrm{FeTiO}_{3}$ : $6 \mathrm{wt} \%$ and b) $\mathrm{FeTiO}_{3} \cdot \mathrm{SiO}_{2} 6 \mathrm{wt} \%$ addition.

Table 5, lists the experimental values obtained for the thermal expansion coefficients between $25-1000^{\circ} \mathrm{C}$ and $25-1450^{\circ} \mathrm{C}$. The $\mathrm{Al}_{2} \mathrm{TiO}_{5}$ without additives has a value slightly negative $a_{25-1000^{\circ} \mathrm{C}}=-0.55 \times 10^{-6^{\circ} \mathrm{C}-1}$. Both additions turn this characteristic value into very low positive ones augmenting with the additive content in each case. This behavior could be explained by the reduction in grain size which causes a microcracking inhibition, as grains boundaries surface increases, i.e., it is necessary a higher energy for cracking (Yoleva et al. 2010). 


\begin{tabular}{|c|c|c|}
\hline Composition & $\mathrm{a}_{25-1000^{\circ} \mathrm{C} \times 10^{-6}{ }^{\circ} \mathrm{C}-1}$ & $\mathrm{a}_{25-1450^{\circ} \mathrm{C}} \times 10^{-6}{ }^{\circ} \mathrm{C}-1$ \\
\hline $\mathrm{Al}_{2} \mathrm{TiO}_{5}$ & -0.55 & 0.87 \\
\hline $\mathrm{FeTiO}_{3}(\%)$ & \multicolumn{2}{|c|}{} \\
\hline 3 & 0.62 & 0.96 \\
\hline 6 & 0.76 & 1.05 \\
\hline 9 & 0.86 & 1.16 \\
\hline $\mathrm{FeTiO}_{3} . \mathrm{SiO}_{2}(\%)$ & & \\
\hline 3 & 0.83 & 1.11 \\
\hline 6 & 0.94 & 1.22 \\
\hline 9 & 1.02 & 1.40 \\
\hline
\end{tabular}

Table 5. Effect of $\mathrm{FeTiO}_{3}$ (pure and concentrated mineral) addition, on $\mathrm{Al}_{2} \mathrm{TiO}_{5}$ Thermal Expansion.

\section{Conclusion}

The evident effect of $\mathrm{FeTiO}_{3}$ additions on $\mathrm{Al}_{2} \mathrm{TiO}_{5}$ was established. An increase of the addition leads to a sensitive decrease on decomposition, this is due to the expected solid solution formed between $\mathrm{Al}_{2} \mathrm{TiO}_{5}$ and the isostructural $\mathrm{Fe}_{2} \mathrm{TiO}_{5}$, the latter being the product of ilmenite decomposition in the oxidizing conditions used.

The ilmenites additions produce a slightly increase in the thermal expansion coefficients being more important with the concentrated mineral addition. Although the values remain acceptable.

The $\mathrm{MnO}$ increases densification by the presence of a localized liquid phase, which allows the rearrangement of particles in the first stage of sintering and also slightly decomposition controls. The ferrosilicon $\left(\mathrm{FeSi}_{2} \cdot \mathrm{SiO}_{2}\right), \mathrm{SiO}_{2}$ reacts with $\mathrm{Al}_{2} \mathrm{O}_{3}$ and the $\mathrm{TiO}_{2}$ forming a liquid phase, allowing rearrangement of particles; however, it lacks of stabilizing effect.

\section{References}

Asbrink, G. \& Magneli, A. (1967) "X-Ray Studies on Some Mixed Oxides Systems of Pseudobrookite Structure", Acta Chem. Scand 21.

Bachmann, J. L. (1948) "Investigations of Properties of Aluminium Oxide and Some Aluminuos Materials"; Ph.D Thesis, Pennsylvania State University.

Barrios de Arenas I. \& Cho S-A. (2011) "Efecto de la adición de ferrosilicio - FeSi 2 en la microestructura y estabilidad del titanato de aluminio- $\mathrm{Al}_{2} \mathrm{TiO}_{5}$." Revista Latinoamericana de Metalurgia y Materiales 2011; 31 (1): 11-19. 
Barrios de Arenas I. (2010) "Estudio de materiales Compuestos de titanato de aluminio $\mathrm{Al}_{2} \mathrm{TiO}_{5}$ estabilizado con ilmenita $\mathrm{Fe}_{2} \mathrm{TiO}_{5}$, reforzado con $\mathrm{Al}_{2} \mathrm{O}_{3}$ y $\mathrm{TiO}_{2}{ }^{\prime \prime}$, Revista Latinoamericana de Metalurgia y Materiales; 30 (2): 210-22.

Bayer, G. (1971) “Thermal Expansión Characteristics and Stability of Pseudobrookite Compounds, $\mathrm{Me}_{3} \mathrm{O}_{5}{ }^{\prime \prime}$. Less Common Metals, 24,[3],129-138.

Bayer, G. (1973) "Thermal Expansion Anisotropy of Oxide Compounds", Proc. Brit. Ceram. Soc. 22, de. D. J. Godfrey. Brit.Cer.Soc., Stoke on Trent, 39-53.

Brown, I. \& Mc Gavin, D. (1994) "Effect of Iron Oxides Additives on $\mathrm{Al}_{2} \mathrm{TiO}_{5}$ Formation" Fourth Euroceramics. Vol 4. 487-492. Faenza editors. Italy

Buessem, W. R .\& Lange, F. F.: "Residual Stresses in Anisotropic Ceramics", Interceram. 15 [3] (1966) 229-231.

Buscaglia, V.; Alvazzi, M.; Nanni, P.; Leoni, M. \& Bottino, C. (1995) “Factors Affecting Microstucture Evolution During Reaction Sintering of $\mathrm{Al}_{2} \mathrm{TiO}_{5}$ Ceramics" Ceramics Charting The Future. Edit. P. Vicenzini, Techna Srl. 1867-1875.

Buscaglia, V.; Carracciolo, F.; Leoni, M.; Nanni, P.; Viviani, M. \& Lematre, J. (1997) "Synthesis, Sintering and Expansion of $\mathrm{Al}_{0.8} \mathrm{Mg}_{0.6} \mathrm{Ti}_{2.1} \mathrm{O}_{5}$ Low Thermal Expansion Material Resistent to Thermal Decomposition" J. Mater. Sci. 32 6525-6531.

Buscaglia, V.; Musenich R.; Nanni, P. \& Leoni, M. (1996) “Solid State Reactions in Ceramics Systems" pp. 123-26 in Proceedings of International Workshop on Advanced Ceramics'96, March 12-14, Inuyama, Japan.

Cleveland J. J. \& Bradt R. C. (1978) “Grain Size Microcracking Relation for Pseudobrookite Oxides", J. Am. Ceram. Soc. 61 [11-12] 478-481.

Cleveland, J.J. (1977) Critical Grain Size for Microcraking in the Pseudobrookite Structure; M.S. Thesis, The Pennsylvania State University, March.

Epicier, T.; Thomas, G.; Wohlfromm, H.; Moya, J. (1991) "High Resolution Electron Microscopy of the Cationic Disorder in $\mathrm{Al}_{2} \mathrm{TiO}_{5}{ }^{\prime \prime}$. J. Mater. Res. 6 [1] 138-145.

Fonseca, A. P \& Baptista, J. (2003) “Efecto de la estequiometria y la temperatura de cocción en el desarrollo de la fase $\mathrm{Al}_{2} \mathrm{TiO}_{5}$ ". Bol. Soc. Esp. Ceram. Vidrio. 42 [2] 65-68.

Freudenberg, B.: "Etude de la reaction à l'état solide: $\mathrm{Al}_{2} \mathrm{O}_{3}+\mathrm{TiO}_{2}-\mathrm{Al}_{2} \mathrm{TiO}_{5}$ ", Tesis Doctoral, Eĉole Polytécnique, Lausanne 1987.

Golberg, D. (1968) “On the Systems Formed by Alumina with Several Trivalent and Tetravalent Metal Oxides, in particular Titanium Oxide" Rev. Int. Hautes Temp. Refract., 5, 181-94.

Hasselman, D. P. \& Singh, J. P. (1979) “Analysis of Thermal Stress Resistance of Microcracked Brittle Ceramics"; Bull. Am. Cer. Soc. 58, [9] 856-860.

Holcombe, C. E. \& Coffey, A .L. (1973) “Calculated X-Ray Powder Diffraction Data for $\beta$ - $\mathrm{Al}_{2}$ $\mathrm{TiO}_{5}$ "; J. Am. Ceram. Soc. 56 [4] 220 -221.

Huber J. \& Heinrich, J. (1988) Keramic im Motor; en ENVICERAM '88, 1st. Int. Symp. And Exposition of Ceramics for Environmental Protection, 7-9 Dic. 1988, Köln, FRG.

Ishitsuka, M., Sao, T., Endo, T. \& Shimada, M. (1987) “Synthesis and Thermal Stability of Aluminium Titanate Solid Solutions" J. Am. Ceram. Soc., 70 69-71.

Jung, J.; Feltz, A.\& Freudenberg, B. (1993) “Improved Thermal Stability of Al - Titanate Solid Solutions", Cfi/ Ber. DKG 70 No. 6 299-301.

Jürgen, H. \& Aldinger, F. (1996) "Applied Phase Studies", Z. Metallkd. 87[11] 841-848. 
Kato, E., Daimon, K. \& Takahashi, J. (1980) “Decomposition Temperature of $\beta-\mathrm{Al}_{2} \mathrm{TiO}_{5}$ ”, J. Am. Ceram. Soc. 63 (1980) 355.

Klug, H. \& Alexander, L. (1954) “X Ray Diffraction Procedures" Edit. John Wiley, p. 410, New York.

Kolomietsev, V.; Suvorov, S.; Makarov, V. \& Butalov, S.(1981) "Sintering and Some Problems of Composite Materials in the $\mathrm{Al}_{2} \mathrm{O}_{3}-\mathrm{Al}_{2} \mathrm{TiO}_{5}$ System" Refractories 22, 627631.

Kuszyk J. A. \& Bradt, R. C.(1973) "Influence of Grain Size on Effects of Thermal Expansion Anisotropy in $\mathrm{MgTi}_{2} \mathrm{O}_{5}{ }^{\prime \prime}$, J. Am. Ceram. Soc., 56 [8] 420-23.

Lang, S.; Fillmore, C. \& Maxwell, L. (1952) “The System Berillia-Alumina-Titania: Phase Relations and General Physical Properties of Three Components Porcelains", J. Res. Natl. Bur. Stand., 48 [4] 301-321.

Lingenberg, W. (1985) “Werkstoffeigenschaften von $\mathrm{Al}_{2} \mathrm{TiO}_{5}$ unter besonderer Berücksichtigung von Bildungs und Zerfallsreaktionen; Disertation, TU Clausthal.

Liu, Z.; Zhao, O. \&Yuan J. J. (1996) “The Effects of Additives on Properties a Structure of Hot Pressed Aluminium Titanate Ceramics". J. Mater. Sci. Lett. 31 90-94.

Milosevski, M. (1997) "Thermal Diffusivity of $\mathrm{Al}_{2} \mathrm{TiO}_{5}, \mathrm{CaTiO}_{3}$ and $\mathrm{BaTiO}_{3}$ " Science of Sintering 29 [2] 105-112.

Milosevski, M.; Ondracek, O.; Milisevska, R.; Spaseska, D. \& Dimeska, A. (1995) “Thermal Expansion and Mechanical Properties of $\mathrm{Al}_{2} \mathrm{TiO}_{5}-\mathrm{SiO}_{2}$ System" Ceramics Charting The Future. Edit. P. Vicenzini, Techna Srl. 1875-1882.

Morishima, H.; Kato, Z.; Uematsu, K.; Saito, K.; Yano, T.; Ootsuka, N. (1987) “Synthesis of Aluminium Titanate - Mullite Composite having High Thermal Shock Resistance"; J. Mater. Sci. Lett. 6 389-390.

Morosin, B. \& Lynch, R. W. (1972) "Structure Studies on $\mathrm{Al}_{2} \mathrm{TiO}_{5}$ at Room Temperature and $600^{\circ} \mathrm{C}^{\prime \prime} ;$ Acta Crystallogr. Sect. B 281040.

Navrostky, A. (1975) "Thermodynamics of Formation of Some Compounds with the Pseudobrookite Structure and of the $\mathrm{FeTi}_{2} \mathrm{O}_{5}-\mathrm{Ti}_{3} \mathrm{O}_{5}$ So lid-Solutions Series"; American Mineralogist 60 249-256.

Ohya, Y. \& Nakagawa, Z. (1996) "Measurement of crack volume due to thermal expasión anisotropy in aluminium titanate ceramics", J. Mater. Sci. 31 1555-1559.

ShannoN, R.D. \& Pask, J.A. (1965) "Kinetics of the Anatase-Rutile Transformation"; J. Am. Ceram. Soc. 48 391-398.

Sheppard L. M. (1989) "A Global Perspective of Advanced Ceramics", Am. Ceram. Soc. Bull. 68 (9) 1624-1633.

Sleepetys, R. \& Vaughan, P. (1969) “Solid Solution of Aluminium Oxide in Rutile Titanium Dioxide" J. Phys. Chem., 73, , 2157 - 62.

Stingl, P.; Heinrich, J. \& Huber, J. (1986) Proceedings of the 2nd International Symposium of ceramic Materials and Component Engines, Lübeck - Travemunde (FRG) April 1986. Edited by W. Bunk and H. Hausner. DKG Bad Honned 369.

Thomas, H. \& Stevens, R. (1989) "Alumina Titanate - A Literature review. Part. 2 Engineering Properties and Thermal Stability"; Br. Cer. Trans. J. 88 184-190.

Tilloca, G. (1991) "Thermal Stabilization of Aluminium Titanate and Properties of Aluminium Solid Solutions" J. Mater. Sci. 26 2809-2814. 
Woermann, E. (1985) Die Thermische Stabilität von Pseudobrookit-Mischkristallen; DFGAbschlu-bericht Tialit (AZ. W. 81/23).

Wohlfromm, H.; Moya T. S. \& Pena P. (1990) "Effect of $\mathrm{ZrSiO}_{4}$ and $\mathrm{MgO}$ Additions on Reaction Sintering and Properties of $\mathrm{Al}_{2} \mathrm{TiO}_{5}$ Based Materials". J. Mater. Sci 25 37533764.

Yoleva, A.; Djambazov, S.; Arsenov, D. \& Hristov, V. (2010) "Effect of $\mathrm{SiO}_{2}$ addition on thermal hysteresis of Aluminum titanate" J. Univ. of Chem. Tech. and Met. 453 269-274. 


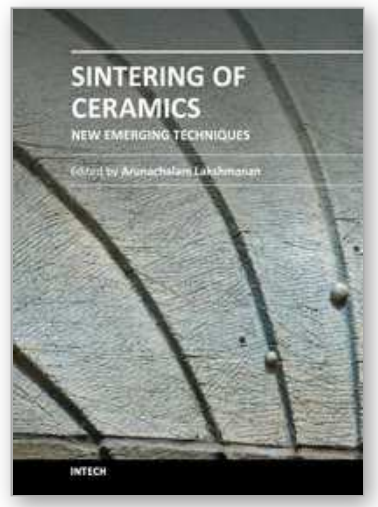

\author{
Sintering of Ceramics - New Emerging Techniques \\ Edited by Dr. Arunachalam Lakshmanan
}

ISBN 978-953-51-0017-1

Hard cover, 610 pages

Publisher InTech

Published online 02, March, 2012

Published in print edition March, 2012

The chapters covered in this book include emerging new techniques on sintering. Major experts in this field contributed to this book and presented their research. Topics covered in this publication include Spark plasma sintering, Magnetic Pulsed compaction, Low Temperature Co-fired Ceramic technology for the preparation of 3-dimesinal circuits, Microwave sintering of thermistor ceramics, Synthesis of Bio-compatible ceramics, Sintering of Rare Earth Doped Bismuth Titanate Ceramics prepared by Soft Combustion, nanostructured ceramics, alternative solid-state reaction routes yielding densified bulk ceramics and nanopowders, Sintering of intermetallic superconductors such as MgB2, impurity doping in luminescence phosphors synthesized using soft techniques, etc. Other advanced sintering techniques such as radiation thermal sintering for the manufacture of thin film solid oxide fuel cells are also described.

\title{
How to reference
}

In order to correctly reference this scholarly work, feel free to copy and paste the following:

Irene Barrios de Arenas (2012). Reactive Sintering of Aluminum Titanate, Sintering of Ceramics - New Emerging Techniques, Dr. Arunachalam Lakshmanan (Ed.), ISBN: 978-953-51-0017-1, InTech, Available from: http://www.intechopen.com/books/sintering-of-ceramics-new-emerging-techniques/reactive-sintering-ofaluminum-titanate

\section{INTECH}

open science | open minds

\author{
InTech Europe \\ University Campus STeP Ri \\ Slavka Krautzeka 83/A \\ 51000 Rijeka, Croatia \\ Phone: +385 (51) 770447 \\ Fax: +385 (51) 686166 \\ www.intechopen.com
}

\author{
InTech China \\ Unit 405, Office Block, Hotel Equatorial Shanghai \\ No.65, Yan An Road (West), Shanghai, 200040, China \\ 中国上海市延安西路65号上海国际贵都大饭店办公楼 405 单元 \\ Phone: +86-21-62489820 \\ Fax: +86-21-62489821
}


(C) 2012 The Author(s). Licensee IntechOpen. This is an open access article distributed under the terms of the Creative Commons Attribution 3.0 License, which permits unrestricted use, distribution, and reproduction in any medium, provided the original work is properly cited. 